\title{
Measuring the impact of donations at the Bottom of the Pyramid (BoP) amid the COVID-19 pandemic
}

\author{
Luiza Ribeiro Alves Cunha ${ }^{1}$ - Bianca B. P. Antunes ${ }^{1}$ (D)

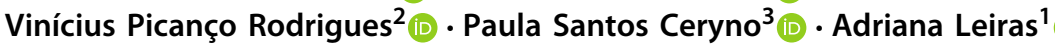

Accepted: 21 October 2021

(c) The Author(s), under exclusive licence to Springer Science+Business Media, LLC, part of Springer Nature 2021

\begin{abstract}
The governments' isolation measures to contain the transmission of COVID-19 imposed a dilemma for the people at the bottom of the pyramid. Since these people have very unreliable sources of income, a dilemma arises: they must either work under risky conditions or refrain from work and suffer from income cuts. Emergency donations of food and cleaning supplies in a pandemic context might be overlooked by government and civil society actors. This paper aims to model the effects of donations on mitigating the negative effects of COVID-19 on vulnerable communities. Applying the system dynamics method, we simulated the behaviour of the pandemic in Rio de Janeiro (Brazil) communities and the impacts that donations of food and cleaning supplies have in these settings. We administered surveys to the beneficiaries and local organisations responsible for the final distribution of donations to gather information from the field operations. The results show that increasing access to cleaning supplies in communities through donations can significantly reduce coronavirus transmission, particularly in high-density and low-resource areas, such as slums in urban settings. In addition, we also show that food donations can increase the vulnerable population's ability to afford necessities, alleviating the stress caused by the pandemic on this portion of the population. Therefore, this work helps decision-makers (such as government and nongovernmental organisations) understand the impacts of donations on controlling outbreaks, especially under COVID-19 conditions, in a low-resource environment and, thus, aid these hard-to-reach populations in a pandemic setting.
\end{abstract}

Keywords Humanitarian operations · Donation · System dynamics · COVID-19 · Pandemic

\section{Introduction}

Over the past several decades, the previous experiences with disease outbreaks have consistently improved society's mechanisms to respond to health crises (Biggerstaff et al., 2014). More recently, the COVID-19 pandemic, caused by the novel coronavirus SARS-CoV-2, has been changing habits and increasing uncertainty about the future, highlighting the importance and urgent need for actions for vulnerable populations during a crisis response (de Camargo Fiorini et al., 2021). Although the global impacts of the pandemic throughout the

Extended author information available on the last page of the article 
world remain unclear, the ensued health and socioeconomic crisis has resulted in the infection of millions of people and caused the death of hundreds of thousands worldwide (WHO, 2020). Moreover, the COVID-19 pandemic will have significant impacts on the economy (Fernandes, 2020; McKibbin \& Fernando, 2020), and it could cost the world approximately US\$11.7 trillion (BusinessToday.In, 2020).

Isolation measures have been highlighted as among the most effective policies aimed at slowing the spread of the disease and, therefore, alleviating the burden on healthcare systems (Antunes et al., 2020; Burch \& Bunt, 2020; Crokidakis, 2020; Giudice et al., 2020). However, these measures impose a dilemma on BoP communities of low- and middle-income countries. These communities are especially vulnerable once people live in impoverished areas, with a lack of basic sanitation, poor quality of life, weak legal mechanisms, low literacy, and frequently have unreliable sources of income (Srivastava et al., 2020). Access to clean water can be a challenge since the private sector is often the last resort provider (Subrahmanyan \& Gomez-Arias, 2008). Such environmental conditions increase the risk of COVID-19 infection, which rapidly spreads over large urban perimeters, making these populations even more vulnerable (Unger \& Riley, 2007).

Global attention is shifting toward developing countries and their BoP, where many humanitarian crises strike (Oloruntoba et al., 2019). It is estimated that 4 billion people worldwide encompass the BoP population. This population is concentrated mainly in Asia, Africa, Eastern Europe, and Latin America, and their number is expected to increase by 50\% until 2040 (Wimschneider et al., 2020). In 2008, Brazil had 25\% of its population among the poorest $50 \%$ of the worldwide population (Dumalanede et al., 2020).

The BoP population depends on an informal economy that is inefficient and poorly distributed (Subrahmanyan \& Gomez-Arias, 2008). This population becomes the worst affected, mainly due to unemployment and lack of structured financial aid. Also, household sustenance becomes a severe challenge, posing a disproportionate toll on children's physical and psychological health (Chakrapani et al., 2020). For example, in Brazilian favelas, it is estimated that $47 \%$ of the inhabitants have informal jobs (Instituto Data Favela, 2020). Besides, most of these jobs demand physical attendance, and thus home office is not feasible. Hence, they must either work under risky conditions or refrain from working and suffer from severe income cuts. The decrease in families' incomes reduces their affordability to access essential food items (Global Food Security Index, 2020), consequently reducing their food security.

Therefore, the impact of the pandemic on this segment of the population is considerably higher relative to other segments. A Brazilian study has shown that the black and brown races were independently associated with increased in-hospital COVID-19 mortality, even after adjusting for sex, age, level of education, region of residence, and comorbidities (Peres et al., 2021). Besides, the difference in the proportion of employed people between black/brown and white races rose from $2.4 \%$ to $5.3 \%$ due to the effects of the pandemic (Ipea, 2021). In Brazilian favelas, $66 \%$ of the residents are either black or brown (Zenker, 2008), even though only $56 \%$ of the overall population are self-declared as those races (IBGE, 2019). Thus, people living in favelas have suffered from higher mortality during the pandemic and higher unemployment rates.

As pandemics result in an abrupt and considerable increase in mortality rates, as well as generate social, political, and economic disruptions (Madhav et al., 2017), they can be viewed as disasters, thus demanding the intervention from humanitarian organisations (HOs) (Anparasan \& Lejeune, 2018; Besiou \& Van Wassenhove, 2020). Policies to control COVID-19- such as food assistance and the search for the achievement of the Sphere Humanitarian Standards for water, sanitation, and hygiene (Corburn et al., 2020) — are goals often 
underachieved by governments in the BoP population, making the humanitarian aid fundamental for the vulnerable communities. HOs-which include a wide range of organisations, from international to locally active non-governmental organisations-respond to disasters by implementing adequate response measures. These measures rely on special emergency funds for initial disaster response missions and donations to fund the relief operations (Turrini et al., 2020). HOs work to plan, implement and control the humanitarian supply chains from raising resources (monetary funds, goods, and services) from donors to the last-mile delivery to meet the urgent needs.

In a complex context, the relevance of the urgent need for humanitarian aid targeted at vulnerable communities is indisputable (Lau et al., 2020; Poole et al., 2020). However, several challenges have surfaced during the pandemic, especially regarding the operationalisation of deliveries of food and cleaning supplies (Corburn et al., 2020; Haynes et al., 2020). At the BoP, the basics infrastructure - facilities and installations such as roads and shelves - that managers take for granted in industrialised and emerging economies are often missing (Fawcett $\&$ Waller, 2015). If not well planned and executed, the distribution of donations considering the outbreak context may cause agglomerations, further disseminating the virus (Leão et al., 2021). Besides, stakeholders might overlook the securement of private and public funds to the delivery of food and cleaning supplies to the BoP, as capturing and quantifying its impacts is not a straightforward process (Ahmen et al., 2020; De Oliveira Andrade, 2020; Rodriguez-Morales et al., 2020).

The financial stability of the disaster victims is fundamental to recovery. However, this aspect is often neglected in the disaster' academic literature (Behl \& Dutta, 2020), and each disaster case has particular characteristics and circumstances regarding how to cope with the ensuing financial shock (Gallagher \& Hartley, 2017). Academic literature on how donations during the COVID-19 pandemic impact the BoP population is scarce. However, the grey literature highlights their positive impact on the most vulnerable population (Chakrapani et al., 2020; Unicef, 2020). In contrast, studies focusing on the context of the healthcare system are abundant. Although reports and booklets have addressed the impact of donations during the COVID-19 pandemic on the most vulnerable population (UNICEF, 2020; Vongkiatkajorn \& Daily, 2020), there is a lack of academic papers in the area. In addition, to the best of our knowledge, there are no studies that quantify these effects. Furthermore, according to Khalid et al. (2020), the BoP literature has mainly focused on business-to-consumer (B2C) issues. Few works study the BoP in humanitarian situations.

In this context, this work seeks to fulfil the exposed research gap, evaluating the potential impacts of the following two policies to improve well-being in vulnerable communities (Corburn et al., 2020): (i) donations of food to increase affordability and (ii) donations of cleaning and hygiene supplies to enhance sanitation procedures and practices. We evaluate the impacts of such donations to provide more access to food supplies and measure the impacts of cleaning supplies on controlling the COVID-19 outbreak in vulnerable communities. Therefore, we aim to answer the following research question: what are the potential impacts of donations of food and cleaning supplies on the COVID-19 contagion rate in the BoP population?

To answer the research question, we surveyed 2155 people living in 143 favelas in Rio de Janeiro (Brazil). Rio de Janeiro was chosen, once it is the Brazilian city with the largest population living in favelas (22\% of the inhabitants), and the average per capita income is below US\$100 per month (IBGE, 2010). It is important to highlight in this context that Brazil reached 584,000 deaths due to COVID-19 by September 2021, a mark only surpassed by the United States, and the economic vulnerability increases the degree of lethality of COVID-19 among the poor in Brazil (Baqui et al., 2020; Peres et al., 2021; Phillips, 2020). Besides, 
Rio de Janeiro is the Brazilian capital with the highest COVID-19 mortality, and it was responsible for $5 \%$ of the deaths in Brazil, while its population represents only $3 \%$ of the total.

We evaluated the impact of donations with a system dynamics (SD) modelling approach. The SD methodology is applied to understand the non-linear behaviour of feedback loops and highly interconnected systems over time and to derive potential future behaviour (Đula \& Größler, 2021). These scenarios support the development of targeted policies to address core issues in the complex systems (Carvalho \& Mazzon, 2020). SD makes use of established causal mechanisms and mathematical relationships aimed at scenario building and policy formulation. Therefore, the SD approach uses known causality to computationally devise scenarios that will potentially support decision-making in various contexts (Sterman et al., 2015). Thus, SD is highly suited to evaluate the potential impacts of different policies on complex systems, where the patterns of behaviour over time are emphasised (Richardson, 2011, 2020). In this paper, we aim at evaluating the potential impacts of different donation mechanisms and policies on the contagion rate of COVID-19 in the BoP population during a pandemic, which is an intrinsically complex system displaying non-linear behaviour over time and high interconnectedness among social, economic, and epidemiological variables (Rahmandad et al., 2021). SD has been widely used to support public policy and healthcare decision-making at a global level (Ghaffarzadegan et al., 2011), as it applies computer simulation models to test these different scenarios and explore "what-if questions" (Álvarez et al., 2015). More particularly, the development of such simulation scenarios can quantify the potential impacts of policy-based interventions (Stummer et al., 2021). In addition, the SD approach can integrate different effects, which are conceptualised as feedback loops, accumulation dynamics, significant system delays, and nonlinear relationships among key variables (Darabi \& Hosseinichimeh, 2020).

SD has been used to study various subjects, including the analysis of trade-offs between a provision of relief assistance and capacity building in humanitarian organisations (Gonçalves, 2011) and investments in disaster management capabilities and pre-positioning of inventory (Kunz et al., 2014). In addition, it is also used to model and simulate epidemics, such as Ebola, Middle East Respiratory Syndrome (MERS), Severe Acute Respiratory Syndrome (SARS), and Malaria (SDS, 2020). More recently, studies applying SD in the context of pandemics gained prominence due to the global context of the coronavirus (Rodrigues et al., 2020; Sahin et al., 2020; Vega, 2020). Thus, SD provided us with the possibility of modelling the dynamics of the coronavirus disease and analysing the different impacts of donations, depending on the type of donations received (gift-in-kind or monetary), distribution channel (gift-in-kind or voucher), donation intensity (quantity and frequency), last-mile delivery mode (organised or disorganised), type of gift-in-kind donation (food or cleaning supplies), and local of purchase relief supplies with received voucher donation (local market x supermarket).

Our paper is structured as follows. Section 2 presents the theoretical foundation of our research, and Sect. 3 the problem statement. Section 4 offers the model development, including the causal loop diagram and the simulation model. Section 5 reports the simulation of the problem, presenting the data collection, model validation, and results. Section 6 consists of the discussion, with theoretical and practical implications. Finally, Sect. 7 summarises the concluding remarks, limitations, and future research avenues. 


\section{Theoretical foundation}

Funding is crucial in the humanitarian operations (Burkart et al., 2016; Mejia et al., 2019). It not only determines the scope of humanitarian actions but also has a significant impact on speed, effectiveness, and efficiency (Burkart et al., 2016). In this sense, the donation is crucial for funding.

Donations can be classified as earmarked or unearmarked. Unearmarked donations go to a general fund, where the donor does not influence the fund allocation among the agency projects (Toyasaki \& Wakolbinger, 2014). Earmarked donations are sent to specific emergency-cause funds (the donors choose the fund allocation) (Aflaki \& Pedraza-Martinez, 2016; Toyasaki \& Wakolbinger, 2014).

Different aspects can influence the donor's decision about the fund allocation, such as the cultural interest in the disaster region and the trust in the local government (Aruga \& Bolt, 2020). If on the one hand, earmarked donations play a key role in humanitarian operations (Tortora \& Steensen, 2014), as it attracts more donations (Aflaki \& Pedraza-Martinez, 2016) and encourages short-term projects focused on tangible results that can be measurable (Baumann, 2021). On the other hand, when only unearmarked is allowed, the expected donation volume is smaller. Still, HOs will have the flexibility to allocate it between the different projects (disaster response or development programs), besides reaching better operational performance (Aflaki \& Pedraza-Martinez, 2016).

A meaningful discussion about donation on literature involves their channels. The current emphasis is on donations through online channels. Online donations have increased over the years (Koksal et al., 2021), rising as an option for traditional monetary donation channels (Koksal et al., 2021). Online donation plays a vital role in vulnerable communities because it is helpful for HOs appeals for funds from many donors (Hou et al., 2021). This scenario highlights the need for online donation platforms once it helps HOs reduce cost as data supplied by the donor and receipts and communication can be done electronically (Koksal et al., 2021). Online crowdfunding, for example, has emerged as a tool for raising funds for emergency response, as proposed by Chakarapani et al., (2020) in the Indian pandemic context. More than 30 percent in crowdfunding platforms is expected to rise in terms of the global transaction value from 2018 to 2022 (Behl \& Dutta, 2019). However, it is fundamental to understand the donor behaviour and factors that increase their engagement concerning online donation platforms. Different authors have contributed to this topic-see Behl and Dutta (2020), Hou et al. (2021), and Yilmaz and Blackburn (2020).

Different forms of donations are explored by academic literature. Johnson (2011) proposes using Corporate Social Responsibility (CSR) funds as an alternative form of financial capitation in the context of humanitarian operations. According to Behl and Dutta (2019), CSR positively affects donation-based crowdfunding to recover after a disaster. The authors highlight the role of CSR initiatives in encouraging crowdfunding activities for social demands by organising campaigns to reach donations with social activities.

The aid delivery to beneficiaries during a disaster response is due by $\mathrm{HO}$ (Fontainha et al., 2017). Government, private, and individual donors can provide gift-in-kind and monetary donations to HOs. However, a monetary donation has the flexibility advantage once the money can be allocated according to the project needs (Dais \& Davis, 2020). In this sense, achieving a higher volume of monetary donation is the primary goal of HOs (Hsu et al., 2021).

Donations can reach the beneficiaries in different ways. A very common categorisation separates gift-in-kind, cash-based donations - cash or voucher. Gift-in-kind donations can 
be categorised into types of products, which have different effects on the population. The donations of cleaning supplies are especially relevant in the COVID-19 pandemic since they enable hygiene practices to reduce virus transmission. On the other hand, the donations of food rise affordability since food comprises approximately $60 \%$ of a household's income in poor areas (von Braun, 2008). Gift-in-kind donations have the advantage of immediately providing beneficiaries with assess to the needed goods (Sabates-Wheeler \& Devereux, 2010). However, they can negatively impact local market sales (Oliveira, 2020). Piotrowicz (2018) mentions the advantages and disadvantages of in-kind food donations, being the immediate access, and to favour women and the elderly some of the benefits, and the transport and storage costs, competition with local markets, and trade some disadvantages.

Therefore, gift-in-kind donations can reduce virus transmission by preventing people from leaving their houses to purchase goods. However, in the humanitarian context, beneficiaries themselves often perform the last-mile distribution, who collect the items at specific sites (Muggy \& Stamm, 2020). Thus, depending on how pick-up procedures are organised, they may generate agglomeration points, spreading the virus. Therefore, last-mile distribution is crucial since delivering humanitarian aid to vulnerable populations may impact health, improve their food security, and indirectly impact the population's social behaviour and movement patterns, which can influence their morbidity and mortality (Aaby et al., 1999). As stressed by the Sphere Standards (Sphere Project, 2011), "distribution points should be established where they are safe and most convenient for the recipients, not based on logistic convenience for the distributing agency." The focus of the last-mile distribution in the relief network is the effective assistance to victims, impacting the "accessibility" in the relief network (Zhang et al., 2020). Accessibility can be related to the response time (Noyan \& Kahvecioğlu, 2018). According to Noyan et al. (2016), network conditions and demographical characteristics affect access to relief supplies. In this sense, it is possible to correlate the social isolation restriction as a variable that influences accessibility.

In turn, the cash-based model reduces the length of traditional humanitarian supply chains by creating a more agile chain once it allows beneficiaries to buy what they need instead of giving them the items (Heaslip et al., 2018). This model speeds up delivery and reduces overall costs (Piotrowicz, 2018). Other advantages of cash-based donations include the costefficiency and the stimulus to production and market growth (Piotrowicz, 2018). However, the risk of theft, inappropriate use, corruption, limited donor resources available, inflation, and the inability to reach the most vulnerable people are pointed as disadvantages of cash donations (Heaslip et al., 2018; Piotrowicz, 2018). Although the cash-based system promotes the empowerment of local markets, supporting the region regenerations (Aruga \& Bolt, 2020), it requires continuous assessment of the local supply availability (Besiou \& Van Wassenhove, 2020). Besides, neighbourhood stores (i.e., "nano stores") typically have poor quality products and high prices (Subrahmanyan \& Gomez-Arias, 2008). However, the displacement to supermarkets usually encompasses crowded public transportation, thus raising the possibility of virus contamination during a pandemic.

Vouchers require distribution in paper or electronic format and have a cash value to be used for payment. However, vouchers have limitations once they are restricted for use with specific suppliers or services and require a network of organisations that accept vouchers as means of payment. Figure 1 summarises the assistance modes (cash, voucher, or in-kind donations) and the donor, donations channels, and allocation modes. 


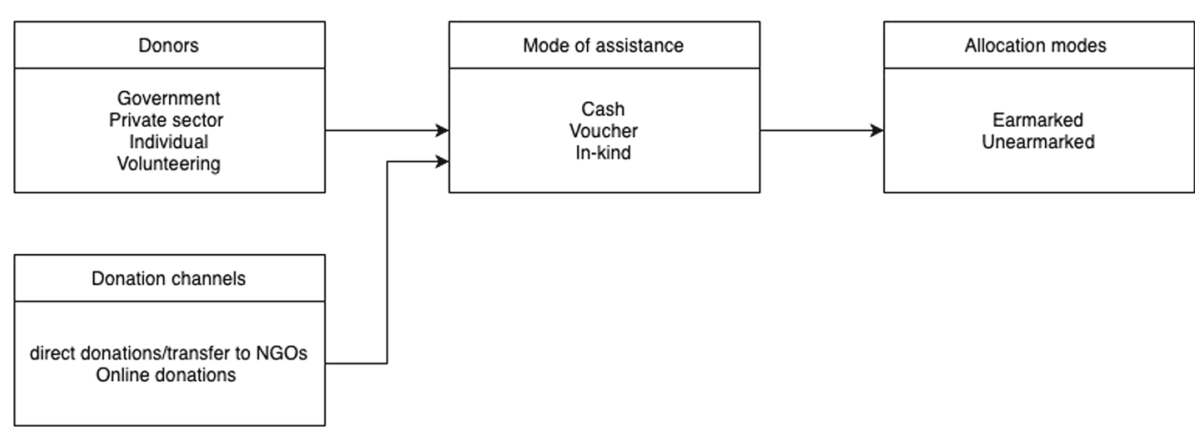

Fig. 1 Schematic representation of the assistance modes, donors, donations channels and allocation modes

\section{Problem statement}

The BoP population living in favelas faces more exposure to COVID-19 as favelas are overcrowded spaces. This population has low resilience to socioeconomic shocks, as people living in favelas usually have irregular incomes due to informal labour, a higher incidence of poverty, and a high dependence on daily income (World Bank Report, 2020). In addition, social distancing and self-isolation might not be options, and access to reliable water supplies for handwashing may not be available. Therefore, favelas require specific responses, as the measures usually applied in other parts of the city may not effectively control the pandemic in these areas.

Amidst this troubling scenario, we model a humanitarian project led by three large nongovernmental organisations. It aims to distribute food and hygiene products to 143 favelas in Rio de Janeiro. Figure 2 presents a schematic representation of the supply chain from monetary donations to the delivery of supplies to the communities.

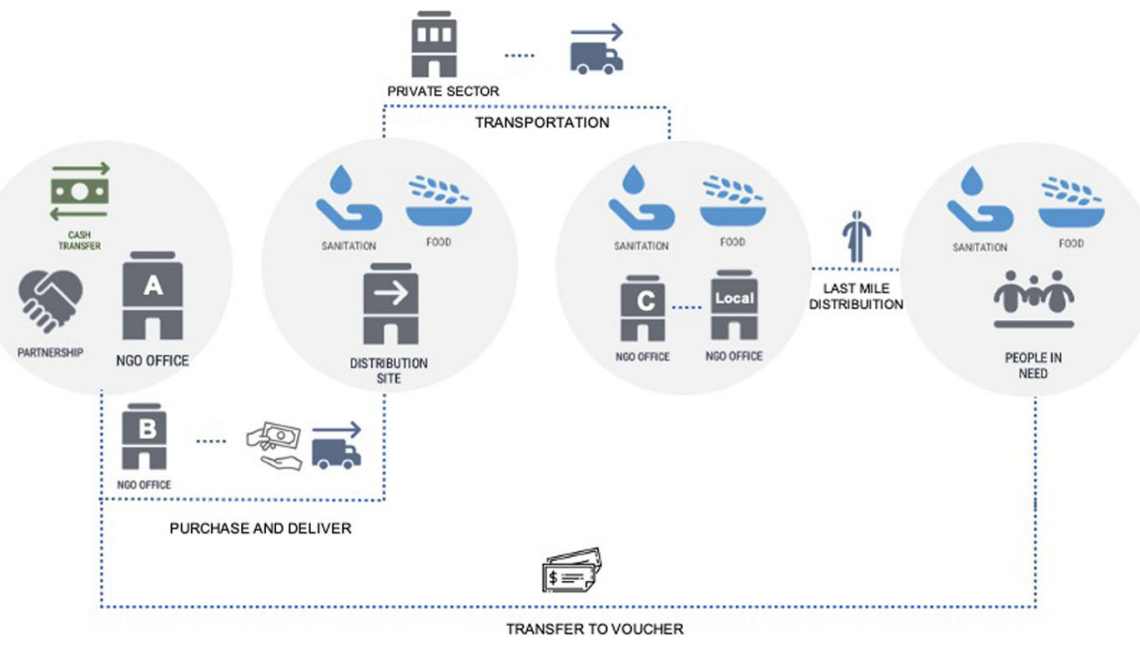

Fig. 2 Schematic representation of the donation chain in Rio de Janeiro communities 
The humanitarian supply chain starts with Organisation A, which receives monetary donations from the private sector and individual donors through an online platform. Organisation A deals strictly with monetary donations for the following two main reasons: (i) reduction in donation movement and manipulation, following the sanitation measures recommended by the World Health Organization (WHO), and (ii) standardisation of donations to meet the demands of the BoP, avoiding the concentration of some types of items.

Organisation B, in turn, uses these donations to purchase the needed goods (food baskets and hygiene kits) or to transfer cash to vouchers. Organisation B is also responsible for sanitising the products and delivering them to the carrier. The carrier, funded by the private sector, transports the items to the local organisations selected by Organisation C. These organisations are responsible for the last-mile distribution to the communities.

After the beneficiaries have received the deliveries, none of the organisations can adequately measure the donations' effects on the communities. Consequently, donors might be unmotivated to make further contributions. In addition, the organisations themselves lack information on these impacts, which becomes an obstacle to improving operations. As resources are scarce, quantifying gains and testing different scenarios become essential to better decision-making processes. For example, part of the donations is made in vouchers to the beneficiaries purchasing their food and cleaning supplies. Logistically, this is an easier and faster option for donors. In addition, it also avoids potential agglomeration when collecting gift-in-kind donations. However, the beneficiaries must leave their houses to buy food and cleaning supplies, which may raise their exposure to the virus. These factors cause a dilemma for organisations, as they cannot quantify the impact of each type of donation.

Other decisions that can influence the operation and impact the control of COVID-19 in these communities include determining the quantity and frequency of donations and defining allocations, i.e., between food and cleaning supplies and between gift-in-kind and voucher donations. More specifically, understanding the counterfactuals becomes imperative; what would be the number of infected and dead people in these communities had the donations not been made? We test the following scenarios in the simulation model: a scenario in which no donations have been made, a scenario in which only gift-in-kind donations are made, a scenario in which only voucher donations are made, and scenarios in which both in-kind and voucher donations occur.

\section{Model development}

SD is a method that qualitatively and quantitatively studies problems within systems displaying dynamic complexity. With the aid of computers, the SD method is geared towards representing high-order multivariate nonlinear systems with multiple feedbacks (Zhong et al., 2018). Thus, once the problem at hand is complex due to the feedback processes-explained in Sect. 4.1-and nonlinearities-displayed in Sect. 4.2—contained in its variables, SD fits as the simulation method to be used. Besides, SD decomposes a complex problem into a set of variables and parameters, assigning mathematical rules to determine their interactions (Diedrichs et al., 2016), a valuable method for problems with many branches. In our case, examples of branches include distribution channel, quantity, and frequency of donations, type of product, delivery mode, and place of purchase, which will be further explained in the following sections.

The SD approach provides decision-makers with a set of tools that allow them to evaluate the potential results of their decisions, such as causal mapping-represented in Sect. 4.1- and 
simulation modelling - detailed in Sect. 4.2. Causal mapping enables the identification of essential variables and their interrelationships, therefore depicting the fundamental structure of the system whose behaviour we want to explore (Sterman, 2000a). The resulting simulation model, in turn, allows decision-makers to envision the behaviour of these variables and their interaction to identify the potential short- and long-term effects of the system (Sterman, 2000a). The high complexity of humanitarian operations makes SD a powerful tool to analyse nonlinear relationships, delays, accumulations, and feedback processes to adjust actions (Gonçalves, 2011).

\subsection{Causal loop diagram}

Causal Loop Diagrams (CLD) represent variables and their relationships, emphasising the structure of feedback loops. All systems consist of positive and negative feedback, and dynamics arise from these loops' interaction (Sterman, 2000a). Positive loops are self-reinforcing, while negative loops are self-correcting, denoting balancing loops. The CLD may also represent key variables in the form of stocks (accumulations) and flows (rates of change) to depict the structure underpinning a particular behaviour over time, commonly referred to as dynamic behaviour (Richardson, 2011; Sterman, 2000a).

Figure 3 shows the CLD combined with a standard stock-and-flow representation that uses the SIR epidemiological model (i.e., Susceptible, Infected, and Recuperated population) as an underlying representation of the COVID-19 spread. The standard SIR model is represented in the compartmentalised model displayed at the bottom of Fig. 3. The model shows each stage-Susceptible, Infected, and Recuperated — as a stock (boxes) with flows connecting each stage of the disease (double-line arrows with hourglasses in the middle). The feedback loops are marked with " $\mathrm{R}$ " for the reinforcing loops and " $\mathrm{B}$ " for balancing loops. Initially proposed by Kermack and McKendrick's (1927), the standard SIR formulation has been widely and consistently used and enhanced in epidemiology over the years. In the SIR model, the contagion process that diffuses the epidemic is represented by the reinforcing loop $R I$ (contagion). As the disease progresses, it infects healthy individuals closing the balancing loop B1 (depletion). Once infected, they either recover (balancing loop B2-recover) and develop immunity or die (balancing loop B3-death). That is, we do not consider reinfection by the virus. The SIR model has been intensively used in local and global efforts to model the ongoing COVID-19 pandemic and simulate its potential effects on health, education, and the economy to inform public policy using a SD approach (Ghaffarzadegan \& Rahmandad, 2020; Rahmandad et al., 2021). In this paper, we use the standard formulation of the SIR epidemiological model as prescribed by the specialised literature (see, e.g., Karanfil et al., 2020; Michael Barton et al., 2020; Sterman, 2000b; Struben, 2020).

The constructs displayed in Fig. 3 are based on literature and accumulated knowledge of the COVID-19 dynamic behaviour. These constructs are further detailed in the following paragraphs. On top of the SIR model, Fig. 3 also shows the usual behaviour of a community, where the families buy food and hygiene products, in addition to other assets not studied in this research, using part (or all) of their monthly income (De Carvalho et al., 2021). Hygiene products are needed to keep the house and its residents clean, which decreases the rate of contagion by viruses (Ribeiro et al., 2021). Balancing loop B4 (income) demonstrates that the lower the family income, the greater the population will work, as they need income to survive. The larger the number of people going to work, the greater the family income and the lesser the social isolation. The higher the family's income, the more it can buy food, therefore 


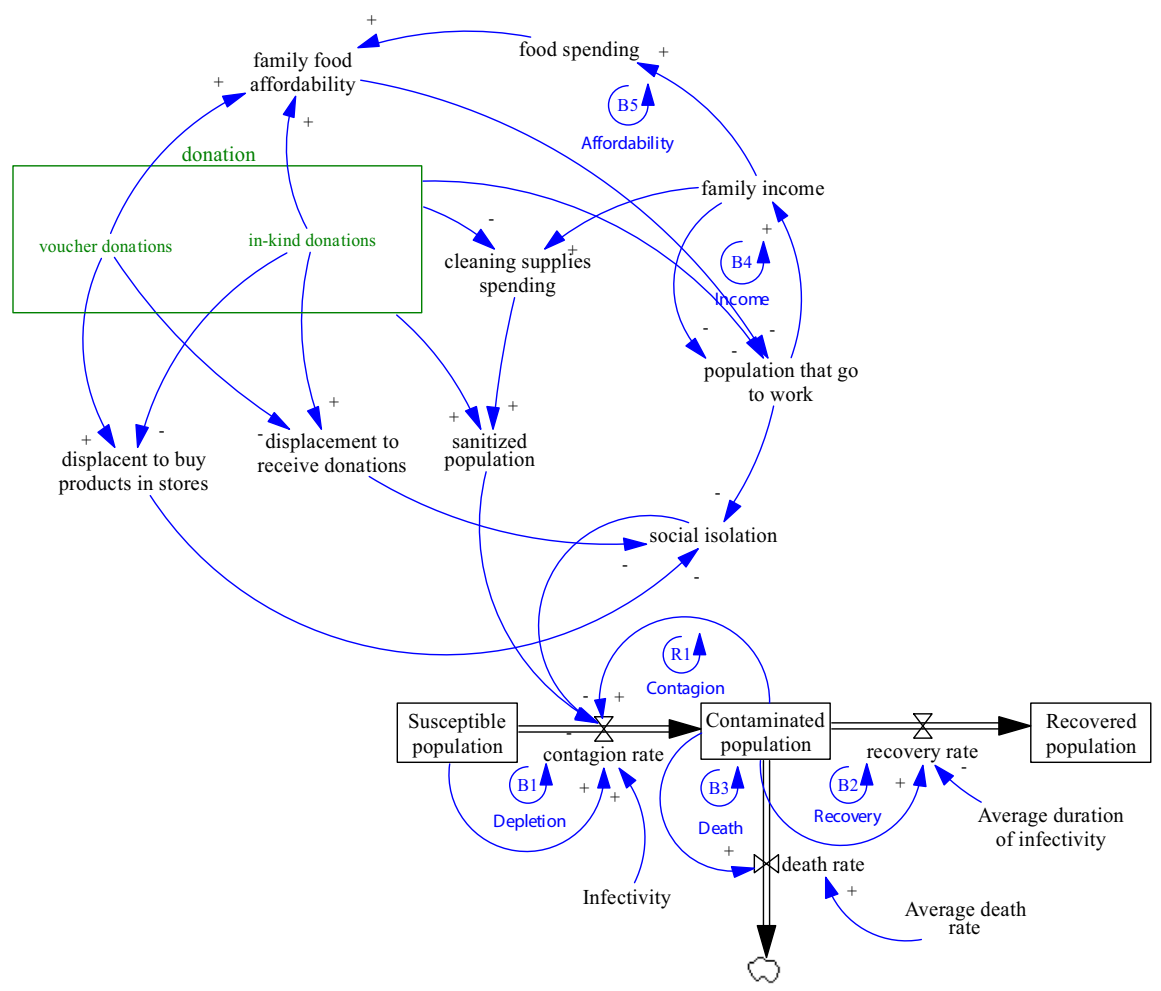

Representation. Physical points of storage (levels) are depicted as boxes; flows between levels are the double-line arrows; double triangles (hourglasses) mean valves that control the flow between levels; blue arrows represent connections between variables and parameters.

Fig. 3 Causal loop diagram depicting the SIR epidemiological model and the typical community purchasing behaviour

presenting higher food affordability and, consequently, the less the population needs to go to work (balancing loop B5-affordability).

With the rapid spread of the COVID-19, the Brazilian government enacted social isolation measures at the local levels in the municipalities to contain the quick dissemination of the virus (Bezerra et al., 2020; Crokidakis, 2020). The CLD in Fig. 3 shows the main changes and effects emerging from the enactment of those measures. When isolation begins, many vulnerable low-income families lose all or part of their income, which is caused either by the isolation itself or the economic crisis it generates (The Lancet, 2020). The income losses are also related to the rigid restrictions on how society operates, as some of these people have informal jobs that rely on the normal functioning of businesses and households-e.g., unregistered domestic workers, informal street workers, or deliverymen (Monteiro de Oliveira et al., 2020; Tavares \& Betti, 2021). The income cuts leave family members with no choice but to return to work, even with enacted social isolation measures. Therefore, the portion of the population that needs to continue working reduces the rate of social isolation and influences contagion dynamics. 
At this point, donations become crucial to maintain families' livelihoods since they support people in complying with social distancing and help keep the most vulnerable population nourished and in sanitary conditions (Bento \& Couto, 2021; Rodrigues et al., 2021). The volume of food and cleaning supplies consumed in a community is based on two main aspects: (i) the population's income and (ii) the number of donations obtained. Cleaning supplies are especially useful in the context of a pandemic, in which a highly infectious disease is rapidly spreading. A high level of hygiene reduces transmission and, therefore, the number of infected people. Food supplies are essential to reduce the effects of income cuts on the food security (Nathan \& Benon, 2020). In addition, food supply donations help keep the population at home since the need to leave home to go to work is reduced (Nathan \& Benon, 2020).

How donations are made also influences the outcomes (Leddy et al., 2020). On the one hand, in-kind donations demand that the beneficiaries leave their houses to obtain donations from a distribution centre; however, there is no need to go shopping for supplies. On the other hand, voucher donations may avoid agglomerations in distribution centres (depending on how they are distributed and recharged) but require travel to the stores (Pereira \& Oliveira, 2020; White et al., 2020). Figure 3 shows how the different types of donations affect the contagion rate.

\subsection{Simulation model}

Considering the presented causal diagram, we developed a simulation model using Vensim Pro (Ventana System), as depicted in Fig. 4. Table 1 summarises the parameters used, including the variable names, brief descriptions, and their units.

The model starts with the cash collection and distribution of donations. The distribution occurs on the following two fronts: (i) distribution of in-kind products; (ii) distribution of vouchers to the population. The number of donations to each front is defined in the model by the variable "Fractional Outflow Split". Therefore, the "Fractional Outflow Split" variable allows the model to capture the amount of money intended for the purchase of food and hygiene products (Eq. 1) to be physically (in-kind) donated to the beneficiaries and to capture the movement of the cash donations, which will increase the monthly family income (Eq. 2).

$$
\begin{aligned}
& \text { Amount intended for inkind donations }= \\
& \qquad \begin{array}{l}
\int[\text { (aggregate outflow } * \text { Fractional Outflow Split }) \\
\quad \text { - expenses with cleaning supplies }- \text { expenses with food }]
\end{array}
\end{aligned}
$$

Income during pandemic $=$

$$
\begin{aligned}
& \int \text { [income during pandemic rate }+(\text { aggrefate out flow } \\
& *(1-\text { Fractional Outflow Split }))- \text { population expenses with cleaning supplies } \\
& \text { - income consumption during pandemic }]
\end{aligned}
$$

Since part of the monetary donations is destined to purchase hygiene products and food baskets to be distributed (in-kind), the model accounts for the litres of hygiene products and kilograms of food bought and donated. The model uses litres of hygiene products and kilos of food in each basket and does not consider price fluctuations resulting from the pandemic. 


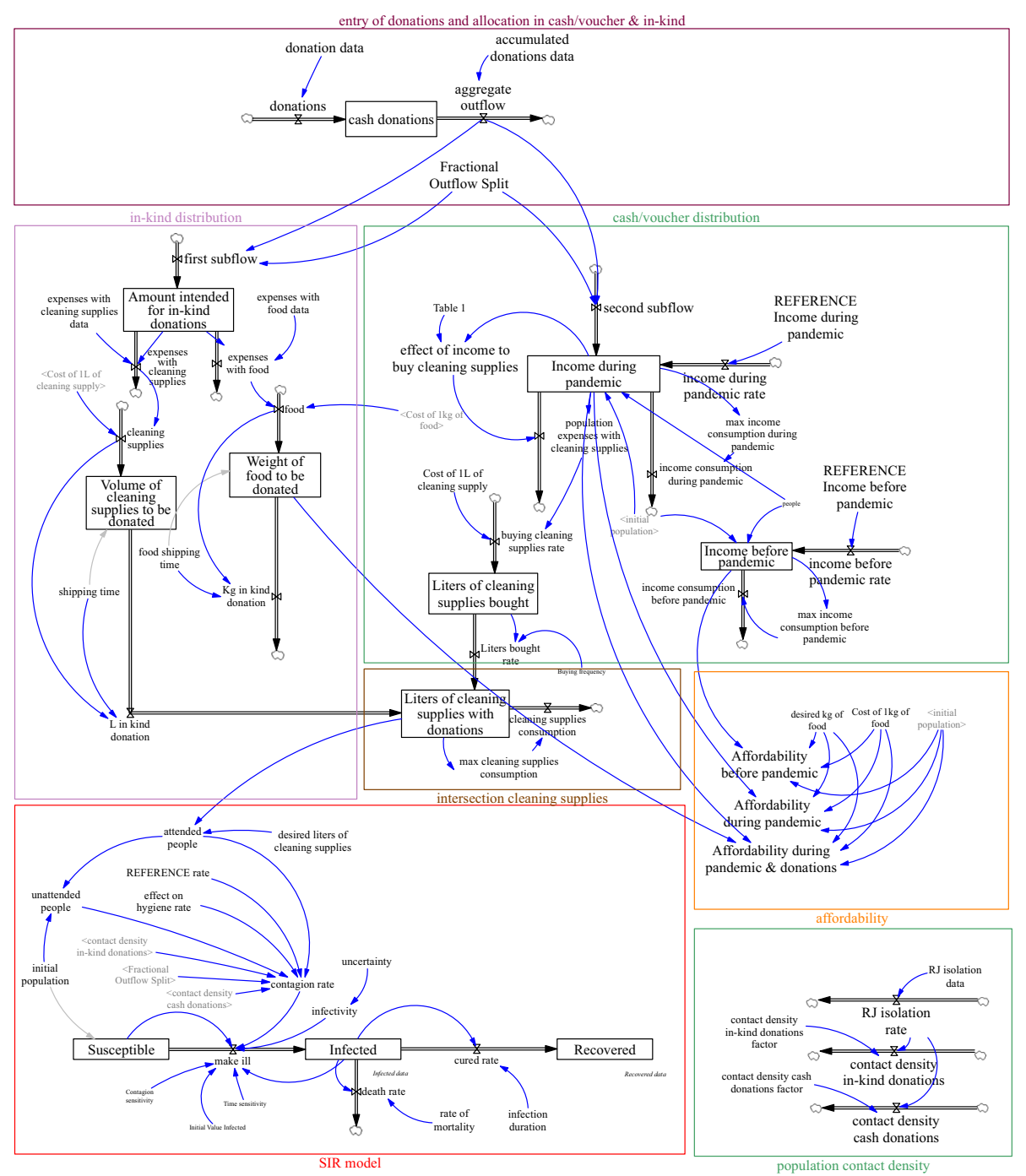

Fig. 4 Complete Simulation Model

This occurs since the organisations may change the products in the basic basket, if necessary, to maintain the same final price and the number of products throughout the period.

When a portion of the donations is designed for voucher distribution and, therefore, influences the population's income, the model calculates the population's spending on hygiene products, the litres of hygiene products purchased by the people, and the population's affordability concerning food with and without donations. As the amount of food and the number of vouchers donated increase the population's income, they also influence food affordability. Thus, we estimated the level of affordability before the pandemic (Eq. 3), during the pandemic without the aid of donations (Eq. 4), and during the pandemic with the assistance of donations (Eq. 5). 
Table 1 Variable descriptions

\begin{tabular}{|c|c|c|}
\hline Variable & Description & Units \\
\hline Affordability before pandemic & $\begin{array}{l}\text { BoP population's ability to purchase food } \\
\text { before the pandemic }\end{array}$ & 1/people \\
\hline Affordability during pandemic & $\begin{array}{l}\text { Ability to buy food by the BoP population } \\
\text { during the pandemic }\end{array}$ & 1/people \\
\hline Affordability during pandemic + donations & $\begin{array}{l}\text { Ability to purchase food by the BoP } \\
\text { population during the pandemic and with } \\
\text { the help of donations }\end{array}$ & 1/people \\
\hline Amount intended for in-kind donations & Financial amount for in-kind donations & Real \\
\hline Attended people & BoP population served by donations & People \\
\hline Cleaning supplies consumption & $\begin{array}{l}\text { Consumption of hygiene products by the } \\
\text { BoP population }\end{array}$ & Litre/day \\
\hline Contact density cash donations & $\begin{array}{l}\text { Contagion density due to contact of the } \\
\text { population that received cash donations }\end{array}$ & Dmnl \\
\hline Contact density in-kind donations & $\begin{array}{l}\text { Contagion density due to contact of the } \\
\text { population that received in-kind } \\
\text { donations }\end{array}$ & Dmnl \\
\hline Contagion rate & Rate of infection by the virus & People \\
\hline Cost of $1 \mathrm{~kg}$ of food & Cost of $1 \mathrm{~kg}$ of food & Real/kilo \\
\hline Desired $\mathrm{kg}$ of food & $\begin{array}{l}\text { Kilograms of food desired to keep the BoP } \\
\text { population fed }\end{array}$ & Kilo \\
\hline Effect on hygiene rate & $\begin{array}{l}\text { Effect that hygiene has on the contagion of } \\
\text { the population by the virus }\end{array}$ & Dmnl \\
\hline Expenses with cleaning supplies & $\begin{array}{l}\text { HO spending on hygiene products to be } \\
\text { donated }\end{array}$ & Real/day \\
\hline Expenses with food & HO spending on food to be donated & Real/day \\
\hline $\begin{array}{l}\text { First subflow (aggregate outflow*Fractional Outflow } \\
\text { Split) }\end{array}$ & $\begin{array}{l}\text { Flow of financial input into the stock } \\
\text { destined to purchase in-kind donations }\end{array}$ & Real/day \\
\hline Income before pandemic & Income before the pandemic & Real \\
\hline Income consumption during pandemic & Population spending during the pandemic & Real/day \\
\hline Income during pandemic & $\begin{array}{l}\text { Income of the BoP population during the } \\
\text { pandemic }\end{array}$ & Real \\
\hline Income during pandemic rate & $\begin{array}{l}\text { Inflow of money into the population's } \\
\text { income stock }\end{array}$ & Real/day \\
\hline Initial population & Initial population & People \\
\hline Liters in kind donation & $\begin{array}{l}\text { Litres of in-kind donations of hygiene } \\
\text { products }\end{array}$ & Litre/day \\
\hline Litres bought rate & $\begin{array}{l}\text { Litres of hygiene products purchased and } \\
\text { donated to the BoP population }\end{array}$ & Litre/day \\
\hline Litres of cleaning supplies with donations & $\begin{array}{l}\text { Litres of hygiene products purchased and } \\
\text { donated to the BoP population }\end{array}$ & Liter \\
\hline population expenses with cleaning supplies & $\begin{array}{l}\text { Population spending on hygiene products } \\
\text { during the pandemic }\end{array}$ & Real/day \\
\hline $\begin{array}{l}\text { Second subflow (aggregate outflow* (1-Fractional } \\
\text { Outflow Split)) }\end{array}$ & $\begin{array}{l}\text { Financial inflow through donations to the } \\
\text { stock of the BoP population's income }\end{array}$ & Real/day \\
\hline
\end{tabular}


Table 1 (continued)

\begin{tabular}{lll}
\hline Variable & Description & Units \\
\hline Unattended people & $\begin{array}{l}\text { BoP population not served by donations } \\
\text { Kilograms of food to be donated to the BoP } \\
\text { population }\end{array}$ & $\begin{array}{l}\text { people } \\
\text { Weight of food to be donated }\end{array}$ \\
\hline
\end{tabular}

Affordability before the pandemic $=$

Income before the pandemic

$\overline{\text { Cost of } 1 \mathrm{~kg} \text { of food } * \text { desired } \mathrm{kg} \text { of food } * \text { initial population }}$

Affordability during the pandemic $=$

REFERENCE Income during pandemic

Cost of $1 \mathrm{~kg}$ of food $*$ desired $\mathrm{kg}$ of food $*$ initial population

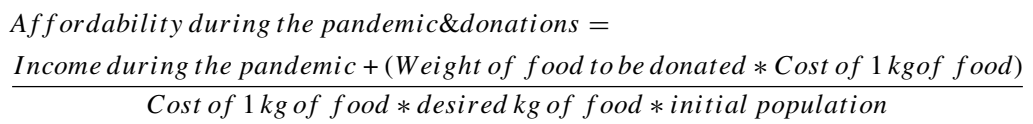

The volume (in litres) of hygiene products donated and distributed and the litres of hygiene products purchased by the population are computed in the variable "Litres of cleaning supplies with donations" (Eq. 6).

$$
\begin{aligned}
& \text { Liters of cleaning supplies with donations }=\int \text { (L in kind donation }+ \text { Liters bought rate } \\
& \text { - cleaning supplies consumption) }
\end{aligned}
$$

The calculated number of litres of cleaning supplies and the population's isolation rate are used to calculate the contagion rate (Eq. 7). Thus, donations of hygiene products are represented in the model as a variable influencing the contagion rate.

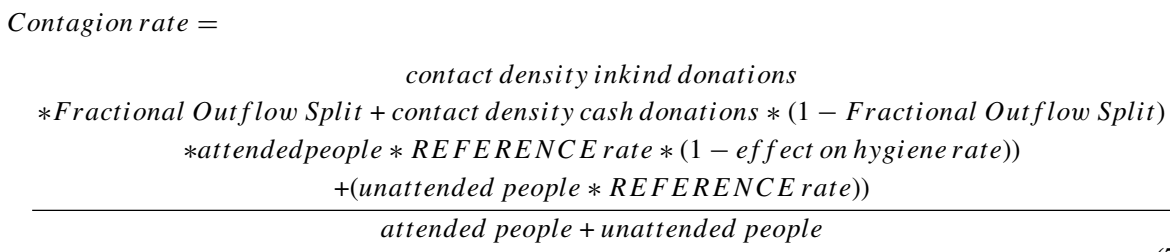

\section{Problem simulation}

This section describes the primary data sources, the model validation, and the simulation model results. 


\subsection{Data collection}

We used the following three main data sources as inputs: (i) data on the number of cases, deaths, and recovered people were retrieved from a data panel that collects information from the communities and the government (Voz das comunidades, 2020); (ii) data on food and hygiene products donated per day were obtained from the project's organisations; and (iii) data on community behaviour were obtained through surveys (Forza, 2002) with the beneficiaries and local organisations that perform the deliveries. The surveys follow the six-step process defined by Forza (2002): connection with the theoretical constructs, survey design, pilot test, data collection, data analysis, and report.

The questionnaires were sent via email; 29 responses were received from local organisations, and 2155 were received from beneficiaries from May 29th to June 14th, 2020. The percentage of answered questions was $85 \%$. The questions submitted to the organisations encompassed an overview of COVID-19 numbers in the communities and the operations performed to deliver the donations. Most organisations (75\%) have a system for beneficiaries to collect donations on-site, exposing them to the disease. However, $81 \%$ of these organisations stated that there were no agglomerations during collections. In addition, $64 \%$ of the organisations preferred to distribute in-kind donations rather than vouchers.

Similarly, the beneficiaries were asked about their preferred type of donation (66\% prefer in-kind), the number of infected people and deaths in their households, and their financial situation (their income during and after the isolation measures, their usual expenses for food and cleaning supplies, and how those expenses would change if their income doubled).

Therefore, the desired expenses on food and cleaning supplies were estimated using the answers from the survey regarding how much the beneficiaries would spend if their income doubled, which resulted in a monthly average of U\$ 144.38 on food and U\$ 39.48 on cleaning supplies per family. Table 2 lists the other parameters of the base scenario.

We ran the model over 210 days since we have data regarding donations during this period. The time interval was 1 day because of the disease dynamics. The model time step is 0.125 , following the rule to set a time step between one-fourth and one-tenth the size of the shortest time constant in the model (Sterman, 2000a).

As for the infection duration, we used COVID-19 hospitalisation data provided by the Brazilian Ministry of Health (Ministério da Saúde, 2020). We then used the average hospital length of stay to proxy the infection duration (15.73 days). Additionally, considering the Brazilian Ministry of Health data, the first COVID-19 case reported in a vulnerable community in Rio was on March 22nd, which is also used in the model for the first infected person. We defined the initial population as 320,000 inhabitants, corresponding to the estimated

Table 2 Standard parameters

\begin{tabular}{ll}
\hline Parameters & Value \\
\hline Time Interval & Days \\
Time Step & 0.125 days \\
Infection Duration & 15.73 days \\
Initial Population & 320,000 beneficiaries \\
First Infected & March 22nd, 2020 \\
REFERENCE contagion rate & 2.91 \\
Effect on hygiene rate & 0.2
\end{tabular}


number of people living in the favelas assisted by the project in the city of Rio de Janeiro (Cavallieri \& Vial, 2012) based on the last census conducted by the Brazilian Institute of Geography and Statistics (IBGE).

Based on the literature, we estimated the effect that the use of cleaning supplies could have on reducing the contagion rate. Aiello et al. (2008) highlighted that using soap and hand sanitisers combined with hand-hygiene education prevented $21 \%$ of respiratory-related illnesses. Aiello and Larson (2002) reviewed 54 papers that associated hygiene measures with infectious diseases and reported that most of them showed a reduction greater than $20 \%$ in infections after implementing these policies. One of these reviewed papers found a $49.7 \%$ reduction in respiratory-related illnesses when students in a specific school were provided with hand sanitisers (Dyer et al., 2000). Therefore, to avoid overestimating the potential of the hygiene supplies donated, we used the lowest of these numbers. We considered that a person has a $20 \%$ lower chance of being infected if the hygiene standards are met.

\subsection{Model validation}

Model validation is crucial to ensure the findings' validity (Barlas, 1996; Sterman, 2000b). We validated our model structure by using the authors' knowledge, the results from our survey, and validity tests, following the protocols put forth by (Schwaninger \& Grösser, 2016), who categorise tests on model-related contexts, model structures, and model behaviours.

Model-related context tests can help avoid ill-conceived models and the use of inappropriate modelling methods (Schwaninger \& Grösser, 2016). In this sense, we performed the model framing test by clearly describing the goal(s) of the model, the involved stakeholders, and the insights gained from using the model. We also performed a test to ensure the adequacy of the methodology, as we explained the use of the SD methodology in the present research. We make the need to use it even more evident when presenting the model due to the dynamic complexity, the feedback mechanisms, and the nonlinear interdependency of structural elements, which is materialised by the mathematical relations of the computational model.

The model structure tests assess whether the model logic is attuned to the real world structure (Schwaninger \& Grösser, 2016). We performed a dimensional consistency test and sensitivity tests using Vensim standard features. The former checks the consistency of the dimensional units to establish the internal validity of the model. The latter assesses changes in the model outcome behaviour given a systematic variation in input parameters, revealing those parameters to which the model behaviour is highly sensitive.

The model behaviour tests are empirical and compare simulation outcomes with actual data. We performed a behaviour anomaly test. In constructing and analysing an SD model, one strives to have it behave like the actual system under study. However, the analyst may detect anomalous features of the model's behaviour, which conflict with the real system's behaviour. Once the behavioural anomaly is traced to the components of the model structure responsible for the anomaly, one often finds flaws in the model assumptions (Schwaninger \& Grösser, 2016). Therefore, we tested for behavioural anomalies throughout the modelling process. Finally, we applied the family member test since a model should generally represent the class of that system to which the case belongs (Schwaninger \& Grösser, 2016). Thus, we analyse and use in the model two families that should be highlighted, i.e., the use of the SIR model, a classic model in the representation of infectious diseases (epidemiological family), and the use of structure elements called the SplitFlow molecule. 


\subsection{Results}

This section first presents the results from the current practice scenario (base scenario), with $95 \%$ of the donations being in-kind donations. This scenario was calibrated according to the isolation rate in RJ. Only 3\% of the in-kind donations were earmarked to purchase hygiene products in the base scenario, while $97 \%$ were allocated for food items. Figure 5 demonstrates how the affordability would have been different if $25 \%, 50 \%$, or $75 \%$ of the in-kind donations were allocated to hygiene products. Therefore, the results show that affordability increases with the volume of food distributed.

Considering the levels of affordability introduced in Fig. 5, we present the number of infections (Fig. 6) for the base scenarios. In our model, the level of affordability does not interfere with the infection rates; thus, the analyses are independent.

In addition, Table 3 shows the number of infected people on day 210 in each base scenario. A $25 \%$ increase in donations of hygiene products would reduce the number of infections by approximately $3 \%$.

To proceed with the analyses, we consider as a premise the $50 \% / 50 \%$ base scenario. We assume that half of the in-kind donations (95\% of the total donations) are hygiene products and the other half are food items. Based on this premise, we can analyse the model's changes considering donations of hygiene products and food.

Table 4 defines the six scenarios we used to analyse the impact of donations on the BoP population. We varied the percentages between in-kind and voucher donations, and in each scenario, we varied the contact density factor. Therefore, the lines (numbers) in Table 4 represent the percentages of donations, while the columns (letters) represent the differences in the contact density factor used.

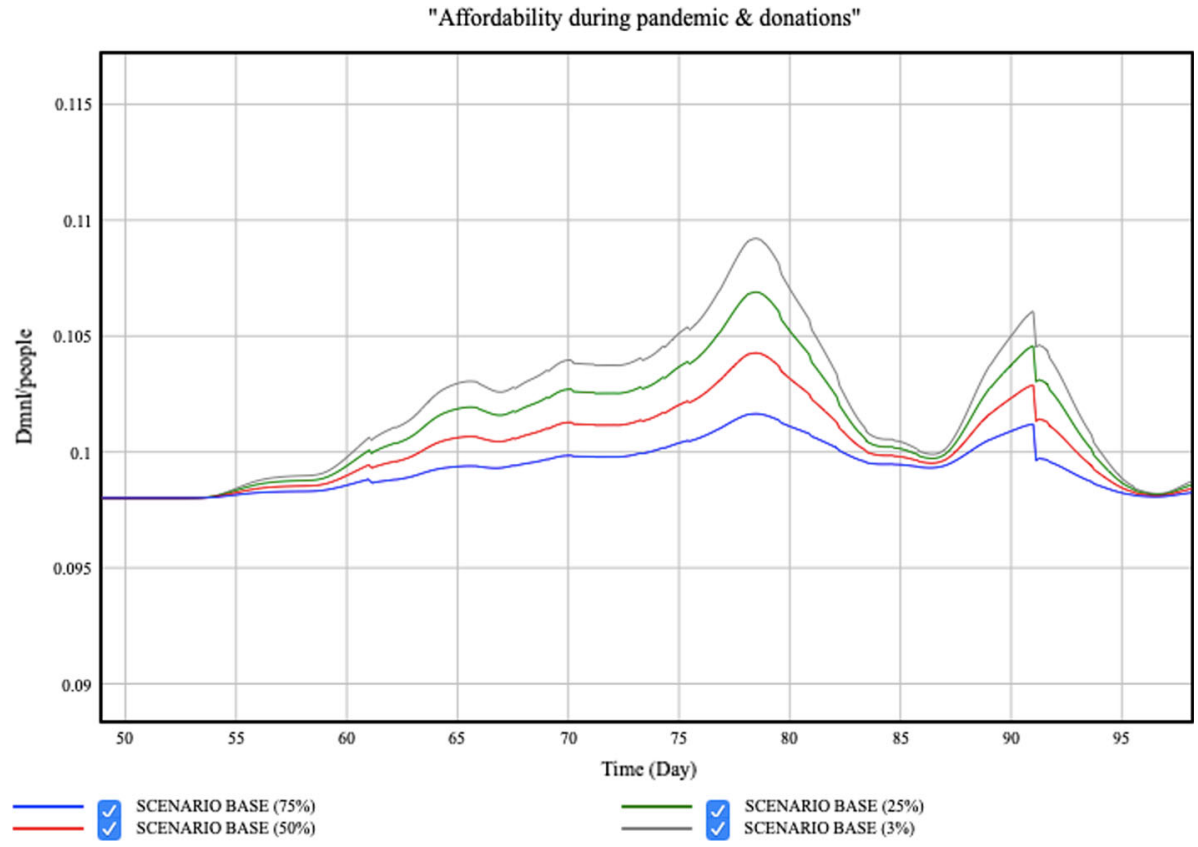

Fig. 5 Affordability with variations of the base scenario 

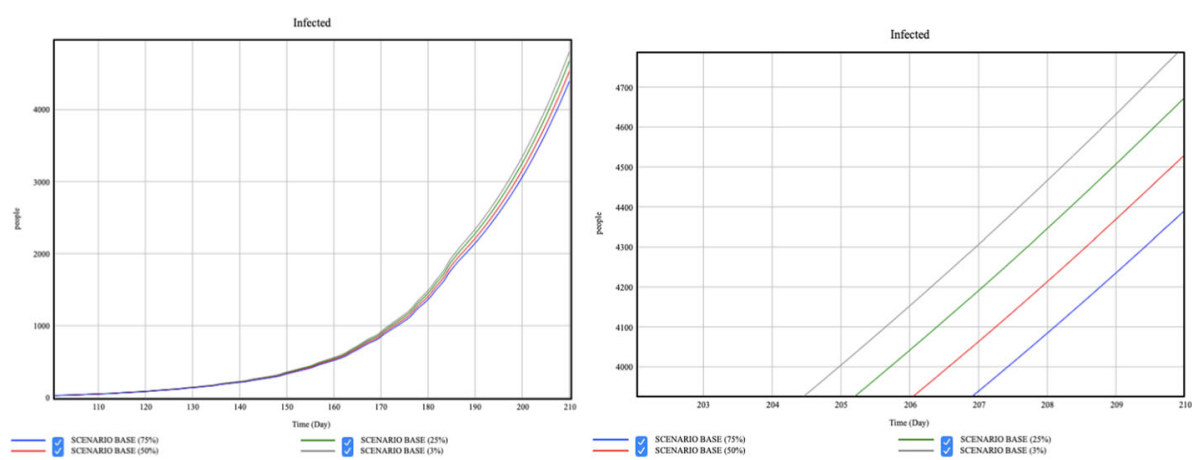

Fig. 6 Number of infected people in different base scenarios

Table 3 Number of infected people on day 210 in the different base scenarios

\begin{tabular}{ll} 
Time (day) & 210 \\
\hline Infected: SCENARIO BASE (75\%) & 4391.93 \\
Infected: SCENARIO BASE (50\%) & 4531.34 \\
Infected: SCENARIO BASE (25\%) & 4674.96 \\
Infected: SCENARIO BASE (3\%) & 4804.91
\end{tabular}

Table 4 Scenario analysis with varying levels of in-kind and cash/voucher donations

\begin{tabular}{|c|c|c|c|c|c|c|c|}
\hline & & \begin{tabular}{|l|} 
SCENARIO 1 \\
\end{tabular} & \begin{tabular}{|l|} 
SCENARIO 2 \\
\end{tabular} & \begin{tabular}{|l|} 
SCENARIO 3 \\
\end{tabular} & SCENARIO 4 & \begin{tabular}{|l|} 
SCENARIO 5 \\
\end{tabular} & SCENARIO 6 \\
\hline $\begin{array}{c}\text { IN-KIND } \\
\text { DONATIONS }\end{array}$ & $\begin{array}{l}\text { Scenario \# (A): distribution at home (0 } \\
\text { contact density factor) } \\
\text { Scenario \# (B): organised distribution } \\
\text { ( } 0.1 \text { contact density factor) } \\
\text { Scenario \# (C): disorganised } \\
\text { distribution ( } 0.2 \text { contact density } \\
\text { factor) }\end{array}$ & $0 \%$ & $100 \%$ & $0 \%$ & $50 \%$ & $70 \%$ & $30 \%$ \\
\hline $\begin{array}{l}\text { CASH/VOUCHER } \\
\text { DONATIONS }\end{array}$ & $\begin{array}{l}\text { Scenario \# (D): organised distribution } \\
\text { and purchase in local market }(0.1+0.2 \\
\text { contact density factor) } \\
\text { Scenario \# }(E) \text { : organised distribution } \\
\text { and purchase in supermarkets }(0.1+0.3 \\
\text { contact density factor) OR } \\
\text { disorganised distribution and purchase } \\
\text { in local market }(0.2+0.2 \text { contact } \\
\text { density factor) } \\
\text { Scenario \# (F): disorganised } \\
\text { distribution and purchase in } \\
\text { supermarkets ( } 0.2+0.3 \text { contact } \\
\text { density factor) }\end{array}$ & $0 \%$ & $0 \%$ & $100 \%$ & $50 \%$ & $30 \%$ & $70 \%$ \\
\hline
\end{tabular}

Scenario 1 considers no donations, Scenario 2 considers only in-kind donations, and Scenario 3 consists of voucher donations only. Scenario 4 considers an equal distribution between in-kind and voucher donations, while Scenarios 5 and 6 prioritise one of the donation types. In each of the six scenarios presented, we performed six other simulations, changing the contact density factor to represent three aspects. First, we consider whether the distribution 

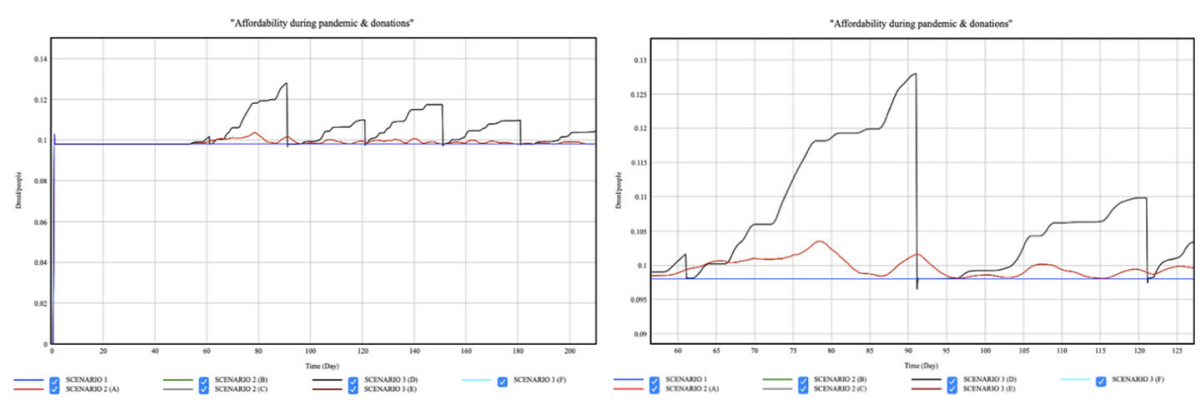

Fig. 7 Affordability results for Scenarios 1, 2 and 3. Schematic representation. Scenario 1 is represented by the blue line; Scenario 2 (all letters) is represented by the red line, as the contact density factor does not influence the affordability results; thus, all lines in scenario 2 overlap; Scenario 3 (all letters) is represented by the black line

of supplies occurred directly in the homes of the populations. Second, whether the distribution occurred in an orderly or disorderly manner is considered. Third, as BoP markets in developing countries are characterised by informal and resource-scarce business environments (Brix-Asala \& Seuring, 2020), we also considered contact density differences if the purchases occurred in local markets-considering that, in this case, the population moves less-or in distant commercial centres-assuming that the population movement is more significant in these cases.

The values used for the contact density factor variable are arbitrary since there is no research showing how much the displacement of the population to nearby or distant markets influences the global isolation rate of a city. However, the values vary from 0.1 to 0.5 to represent low and high contact densities, respectively. In that case, when we have an organised distribution with the population buying goods at supermarkets, we have the same contact density (0.4) as a disorganised distribution but with the beneficiaries shopping at local markets. Therefore, we combined these two variations as one.

Figure 7 shows the results of the first three scenarios-without donations, with $100 \%$ in-kind donations, and with $100 \%$ voucher donations. Figure 7 shows that the affordability in Scenario 1 -without donations - is very low, meaning the population would have difficulty buying food. Scenario 2 has better accessibility than scenario 1, but it is still reduced. Even though Scenario 2 is best considering the number of infected people, Scenario 3 presents an enhanced result considering affordability since, in this scenario, vouchers are given to the population, who decides the allocation of food and hygiene products.

It should be noted that the different contact density factors do not interfere with the affordability results, as the affordability only encompasses the ability to buy food and is not related to the number of infected people. As in the infection results, scenarios 4, 5, and 6 fall between scenarios 2 and 3 (Fig. 8), as they are combinations of these two extreme scenarios.

Table 5 shows the affordability results of all scenarios on day 91 , the day that presented the highest affordability value. The affordability increases $20 \%$ when all donations are performed in vouchers (Scenario 3) compared to in-kind donations (Scenario 2).

For the number of infections, Scenario 1 has the steepest infection curve; it fails to reach the plateau of the curve not to overload the healthcare system. This scenario (without donations) presents results like those with a contact density factor of 0.5 . Therefore, we can state that voucher donations with a disorganised distribution of vouchers and purchases in supermarkets 


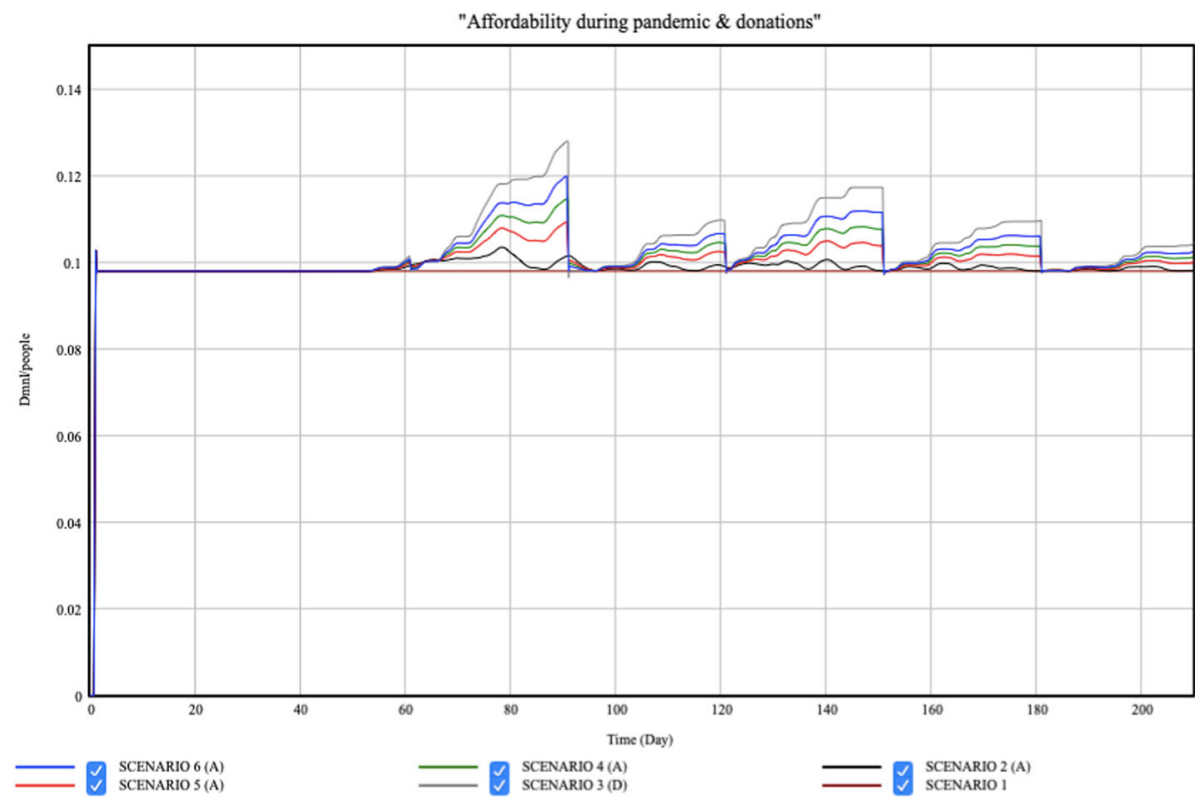

Fig. 8 Affordability results for scenarios 1,2,3, 4, 5 and 6. Schematic representation. As the contact density factor does not influence the affordability results, all possibilities of letters (which represent the contact density) in a specific scenario have the same result, which is why we can analyse scenario 3 (D) with the other scenarios in $(\mathrm{A})$

Table 5 Affordability results on day 91
Time (Day) $\quad 91$

Affordability during pandemic \& donations:

0.120061 SCENARIO 6 (A)

Affordability during pandemic \& donations:

0.109493

SCENARIO 5 (A)

Affordability during pandemic \& donations: SCENARIO 4 (A)

Affordability during pandemic \& donations: SCENARIO 3 (A)

Affordability during pandemic \& donations: SCENARIO 2 (A)

Affordability during pandemic \& donations: SCENARIO 1
0.0980136

far from the beneficiaries' homes (having to take public transport) could result in infection numbers like the scenario where no donations were made.

Figure 9 demonstrates that the infected curve flattens according to the different contact density factors. Scenario 2 (A) has the lowest infection curve since this scenario has a home distribution (with no level of contact). The next curve is that of Scenario 2 (B), followed by Scenario 2 (C), Scenario 3 (D), Scenario 3 (E), and Scenario 3 (F). 


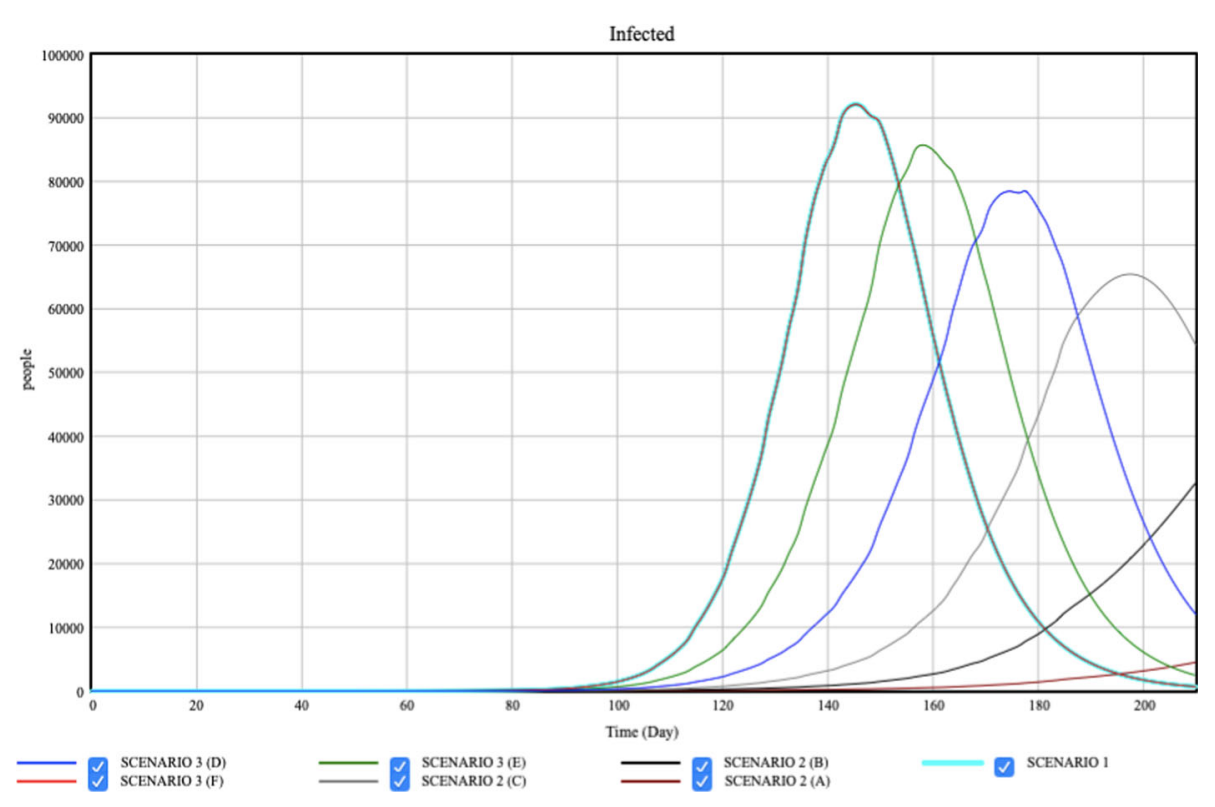

Fig. 9 Number of infected people in Scenarios 1,2 and 3

The peak of cases when the contact density factor is 0.5 - scenario $3(\mathrm{~F})$ - is on day 145 , with 92,072 people infected. Considering the contact density as 0 - scenario 2 (A) - the highest point of the infection curve is on day 210, with 4517 infected (Table 6).

Scenarios 4, 5, and 6 show the same infection curve behaviour and are always between the curves of scenarios 2 and 3, as shown in Figs. 10 and 11.

Considering the infection curves presented, scenario 2 demonstrates better behaviour. Thus, scenario 2 presents a lower number of infected people. However, these results also vary according to the policy adopted when distributing the donations and how the beneficiaries to shop (local vs. supermarkets).

Table 6 Infected data results

\begin{tabular}{lclc}
\hline Time (day) & 145 & Time (day) & 210 \\
\hline Infected: SCENARIO 2 (A) & 266.966 & Infected: SCENARIO 2 (A) & 4517.58 \\
Infected: SCENARIO 2 (B) & 1103.3 & Infected: SCENARIO 2 (B) & $32,774.6$ \\
Infected: SCENARIO 2 (C) & 4470.25 & Infected: SCENARIO 2 (C) & $54,177.1$ \\
Infected: SCENARIO 3 (D) & $17,849.7$ & Infected: SCENARIO 3 (D) & $11,990.7$ \\
Infected: SCENARIO 3 (E) & $53,798.8$ & Infected: SCENARIO 3 (E) & 2441.01 \\
Infected: SCENARIO 3 (F) & $92,072.1$ & Infected: SCENARIO 3 (F) & 680.479 \\
Infected: SCENARIO 1 & $92,117.6$ & Infected: SCENARIO 1 & 678.041 \\
\hline
\end{tabular}



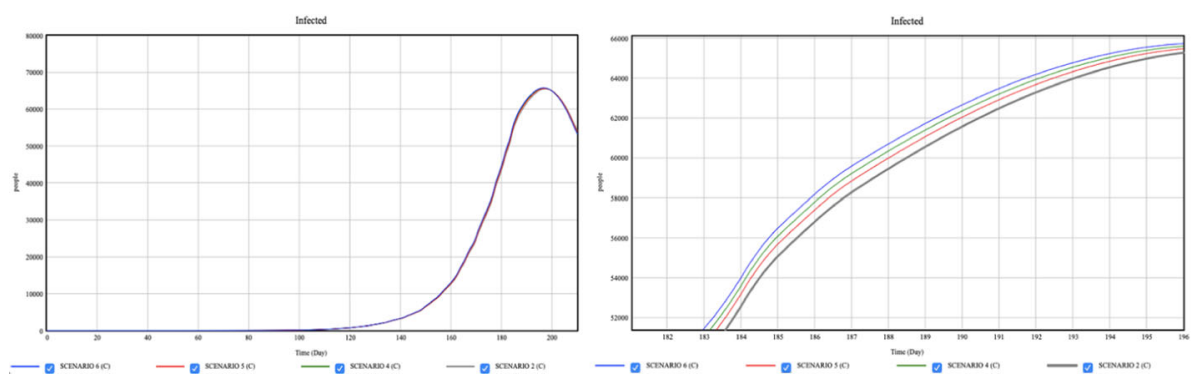

Fig. 10 Schematic representation showing that scenarios 4, 5, and 6 remain above scenario 2
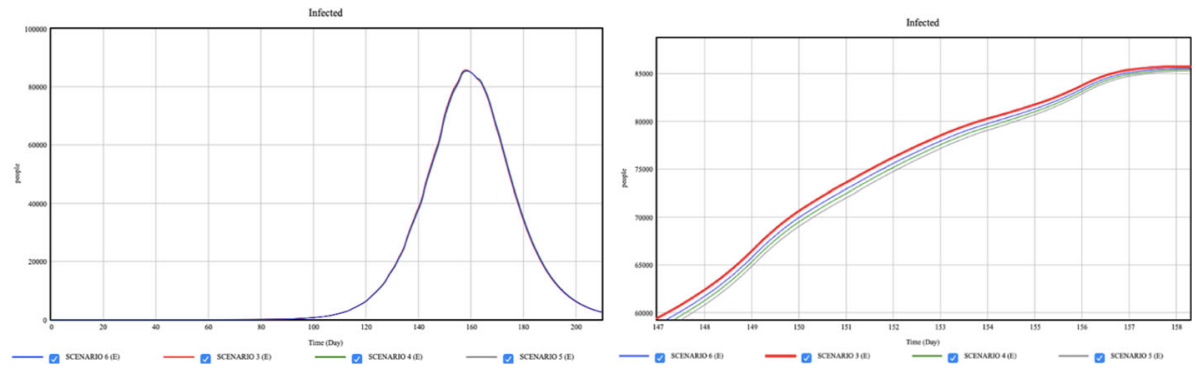

Fig. 11 Schematic representation showing that scenarios 4, 5, and 6 remain below scenario 3

\section{Discussion}

We investigated the impacts of donating food and cleaning supplies to the vulnerable population in the BoP. We focused on two main aspects, i.e., affordability (food donations) and epidemic control (cleaning supply donations). We built an SD model based on empirical data collected from RJ communities and HOs. This section presents the practical discussion (Sect. 6.1) concerning our main results and the theoretical discussion (Sect. 6.2) considering the research subject and other relevant literature.

\subsection{Practical discussion}

Our research marks the first attempt of assessing the impact that donations have on the BoP populations, contributing to fulfil an academic research gap. We also show the importance of humanitarian aid in a pandemic context, given that the government has failed to appropriately support community inhabitants, especially during the COVID-19 outbreak (Andrade, 2020).

Our research findings emphasise that donations can improve the RJ BoP population's food affordability and reduce the number of infected people during a pandemic. This was only possible because of the effective participation of different stakeholders. The relevance of donations appears when governments are unable to meet the needs of inhabitants in such a short time frame. Therefore, we advocate in favour of stakeholder coordination so that a more significant portion of the population can receive aid.

Efficiency can be significantly affected depending on the type of donation made. Our modelling demonstrated that voucher donation has better results for food affordability. Reports 
on this topic showed that the direct distribution of food to the BoP caused an undesired side effect of food trading among residents in these vulnerable communities, affecting local sales, which were already severely affected by the ensued economic and sanitary crisis (Oliveira, 2020). Injecting money into the local economy through vouchers supports the maintenance of the financial system. In addition, last-mile deliveries represent a particular obstacle to distributing in-kind donations, as agglomerations contribute to the spread of the disease.

Our findings also demonstrated that in-kind donations present better results regarding the number of infected people. However, that is mainly because it prevents people from shopping and, therefore, becoming infected. Thus, how organisations deliver goods is also relevant. Agglomerations at donation pick-ups could significantly change the results of donation efforts. Therefore, actions such as delivering goods to beneficiaries' houses or organising pick-ups are also necessary when planning donations.

We emphasise that the results performed here do not encompass all possible scenarios. For instance, when we increase the percentage of donations spent on cleaning supplies, the donation of food decreases. If the beneficiaries do not have the necessary amount of food, they will need to leave their houses, which could cause an increase in the number of infections. Therefore, our results should be interpreted with caution. Even though our model shows that an increase in the percentage of cleaning supplies donated generates a decrease in the number of infections, it also reduces the population's affordability, eventually leading to more infections.

However, the importance of donations to support the BoP during crises, such as the pandemic, is indisputable. The type of donation, i.e., in-kind or voucher, depends on the primary needs of the beneficiaries and the project's objectives. Thus, if the focus is on an epidemiological issue focused on reducing cases, our model suggests prioritising in-kind donations and hygiene products. However, if the concern is about population food affordability, and local commerce, our results suggest voucher donations.

\subsection{Theoretical discussion}

Once a disaster strikes, financial aid is offered to the victims by different sources. However, most financial aid is temporary and short term (Behl \& Dutta, 2019; Behl et al., 2019). The humanitarian project described and studied in this research, for example, is funded by individual, group contributions, and companies in the form of direct transfers to the HOs. However, it is not possible to determine how long this project will raise money. Other studies claim that the government is commonly the only stakeholder offering long-term support to the victims (Behl \& Dutta, 2019).

Once the government understands/is aware that the outbreak will cause economic impacts, containment measures (public policies) such as social support programs, food security plans and government financial assistance must be implemented. Cooperation and collaboration between the stakeholders are essential so that there is no rework during times of crisis. HOs and private companies can and should come together to help through donations. Alternatively, there are other sources of financial capitation, as crowdfunding and corporate social responsibility (CSR). Policies should be created regarding transportation and distribution plans, demand analysis plans, information-sharing tools, and even workforce adjustment once the HOs and companies can even use the BoP population to carry out the work.

Based on the data collected and the results achieved, we reinforce the need to engage other stakeholders beyond the government in donation campaigns. Supporting coordination 
efforts and collaboration between stakeholders (such as private and public donors, beneficiaries, HOs, and suppliers) is essential to fight the pandemic. In addition to corroborating the findings of Burkart et al. (2016), Fontainha et al. (2017), and Turrini et al. (2020), we believe that HOs should focus on aiding vulnerable populations during the pandemic (Vongkiatkajorn \& Daily, 2020), ensuring that they receive supplies on time and in adequate quantities (Chakravarty, 2014). Our engagement with communities and HOs during data collection and the results we achieved emphasise that the effectiveness of donations is secured when incentives are aligned, communication among organisations is transparent, and stakeholders have clear roles. Furthermore, strategically designed donation programs must be deployed in operational practices, and activities should involve private-public arrangements, especially during a pandemic.

Our results are potentially applicable to other regions in the world, especially other lowand middle-income countries. In India, for example, as in Brazil, the BoP population has been severely affected by the pandemic. Chakrapani et al. (2020) argue that the lockdown scenario for BoP workers from India implied acute unemployment, lack of monetary resources, and an additional burden of supporting their families. The same phenomenon was experienced in the RJ population of BoP workers. Most of them, who are daily wagers, have lost their jobs, facing problems meeting their basic daily needs. Considering the similarity between the scenarios, we firmly believe that the types of donations investigated in this study would also reduce the number of infected people, deaths, and food security of this portion of the population. However, according to Wimschneider et al. (2020), a typical characteristic of the Asian BoP is rural living circumstances, contrasting with the predominantly urban BoP in Latin America and Caribean, where $77 \%$ of these people are located in central city areas. Therefore, although donations can have positive results in countries with rural BoP populations, we believe that the results may differ slightly compared to regions with predominantly urban BoP populations.

\section{Conclusions}

This study aimed to comprehensively study the complexity of pandemics such as COVID19 and the impacts of donations on reducing difficulties faced by the BoP population. The objective of our analyses was twofold: to determine how donations can reduce the number of people infected and deaths and how donations can secure food affordability. Regarding the number of infected people, our analysis (Table 6) demonstrates that the highest point of the infection curve could be reduced according to different scenarios, showing a difference of more than 57 thousand infected people between the scenario with the highest peak and that with the lowest peak. Concerning food affordability, we argue that affordability increases $20 \%$ when all donations are in the form of vouchers/cash (Scenario 3) compared to all in-kind donations (Scenario 2).

These numbers can serve as a basis for policymakers to aid vulnerable communities, especially during crises in which resources are scarce and must be efficiently explored. Thus, local governments can better plan and evaluate how their actions will impact people in need, including what and how to donate, besides federal government financial assistance. Furthermore, we hope that this work will encourage private for-profit organisations to participate in such actions, as it sheds light on the importance and impact of donations to these people.

Our study contributes to the literature by gathering evidence and providing insights into the role of donations to vulnerable communities in complex settings during periods of crisis. As little research concerning donations during the pandemic is found in the current literature, 
our paper is different from earlier studies on the particular topics of donations and pandemic responses as it: (i) focuses on the particular characteristics of donations (e.g., distribution channel, quantity, frequency, type of product, delivery mode, and place of purchase goods with received voucher donation) and its effect on contagion rate in BoP population; (ii) unearths the dynamic patterns of behaviour emerging from the structured operations of donations and how they relate to the COVID-19 dynamics and (iii) explores the complex realities of the BoP population living in Brazilian favelas, which lack access to proper infrastructure and sanitation.

Additionally, our study corroborates results found in the grey literature, which emphasises that donations can limit the spread of the virus, protect key workers, and reduce the impact on some of the world's most vulnerable families (UNICEF, 2020). We highlight as our main contributions the development of an SD model that can capture, in addition to a classic SIR model, different aspects of social behaviour, including isolation, purchase of food and cleaning supplies, income, and donations. We also emphasise that the data were not empirically assumed but were estimated based on 2155 survey responses from beneficiaries. Therefore, we hope that this research can justify the importance of donations and public-private-people relationships. We also expect to shed light on the experiences of BoP communities during times of emergency.

Our research has some limitations, which highlight possibilities for future studies. The first limitation is adopting a classic, however simple, epidemiological model (SIR model). As our research focus was not on epidemiological modelling, we opted for the classic SIR model. However, we suggest that future studies use more complex epidemiological models considering other factors, such as the number of hospitalisations and the number of beds available to the BoP population. The second concern is the isolation rates since we only consider changes of $1 \%$ and $2 \%$ according to the population movement. We also advocate the need for studies that describe ways in which donor motivation can be sustained since the lack of feedback might be discouraging. Also, concerning the model, we suggest that future studies consider variation in food prices during the pandemic, showing that the population's purchasing power was altered due to price fluctuations.

Finally, even though we have addressed the affordability topic, other pillars to examine food security are fundamental in future studies to define the direct relationship with the food security of the BoP population. The future scope of our work encompasses the triad composed of affordability (the ability of consumers to purchase food), availability (sufficiency of the national food supply and national capacity to disseminate food), and quality (variety and nutritional quality of average diets), established dimensions necessary to examine food security (EIU, 2019).

Acknowledgements The authors acknowledge the support of the Coordination for the Improvement of Higher Education Personnel (CAPES) [88887.199861/2018-00; 88887.595951/2020-00 - Finance Code 001], the National Council for Scientific and Technological Development (CNPq) [308084/2019-5], and the Foundation for Support of Research in the State of Rio de Janeiro (FAPERJ) [E-26/ 201.384/2021; SEI-260003/002705/2020; 211.029/2019]. We also acknowledge the organizations involved in the studied humanitarian project. We emphasize that, for more information, it is possible to access the online simulator available at: https://www.forio.com/app/labhands/anor.

\section{References}

Aaby, P., Gomes, J., Fernandes, M., Djana, Q., Lisse, I., \& Jensen, H. (1999). Nutritional status and mortality of refugee and resident children in a non-camp setting during conflict: Follow up study in Guinea-Bissau. BMJ, 319(7214), 878 . 
Aflaki, A., \& Pedraza-Martinez, A. J. (2016). Humanitarian funding in a multi-donor market with donation uncertainty. Production and Operations Management, 25(7), 1274-1291.

Ahmen, F., Ahmed, N., Pissarides, C., \& Stiglitz, J. (2020). Why inequality could spread COVID-19. Lancet Publ Health, 5(5), E240.

Aiello, A. E., Coulborn, R. M., Perez, V., \& Larson, E. L. (2008). Effect of hand hygiene on infectious disease risk in the community setting: A meta-analysis. American Journal of Public Health, 98(8), 1372-1381.

Aiello, A. E., \& Larson, E. L. (2002). What is the evidence for a causal link between hygiene and infections? Lancet Infectious Diseases, 2(2), 103-110.

Álvarez, E., Donado-Campos, J., \& Morilla, F. (2015). New coronavirus outbreak. Lessons learned from the severe acute respiratory syndrome epidemic. Epidemiology and Infection, 143(13), 2882-2893.

Andrade, R. (2020). The Brazilian slums hiring their own doctors to fight covid-19. The BMJ, 369, 2-3.

Anparasan, A., \& Lejeune, M. (2018). Data laboratory for supply chain response models during epidemic outbreaks. Annals of Operations Research, 270(6), 1-12.

Antunes, B. B., de Peres, P., Baião, I. T, Ranzani, F. A., dos Santos Lourenço Bastos, O. T., de Araújo Batista da Silva, L., \& de Souza, A. G. F. G., et al. (2020). Progression of confirmed COVID-19 cases after the implementation of control measures. Revista Brasileira de Terapia Intensiva 32(2), 213-223

Aruga, K., \& Bolt, T. (2020). Is the willingness to support disaster regions through consumption related to altruism? A discrete choice experiment. Journal of Disaster Risk Reduction, 50, 101876.

Baqui, P., Bica, I., Marra, V., Ercole, A., \& van der Schaar, M. (2020). "Ethnic and regional variations in hospital mortality from COVID-19 in Brazil: A cross-sectional observational study. The Lancet Global Health, 20, 6-8.

Barlas, Y. (1996). Formal aspects of model validity and validation in system dynamics. System Dynamics Review, 12, 183-210.

Baumann, M. O. (2021). How earmarking has become self-perpetuating in United Nations development cooperation. Development Policy Review, 39(3), 343-359.

Behl, A., \& Dutta, P. (2019). Social and financial aid for disaster relief operations using CSR and crowdfunding: Moderating effect of information quality. Benchmarking: An International Journal. https://doi.org/10. 1108/BIJ-08-2019-0372.

Behl, A., \& Dutta, P. (2020). Engaging donors on crowdfunding platform in disaster relief operations (DRO) using gamification: A civic voluntary model (CVM) approach. International Journal of Information Management, 54, 102140.

Behl, A., Dutta, P., \& Chavan, M. (2019). Study of E-governance and online donors for achieving financial resilience post natural disasters. In Proceedings of the 12th International Conference on Theory and Practice of Electronic Governance, New York, pp. 27-35.

Bento, F., \& Couto, K. C. (2021). A behavioral perspective on community resilience during the covid-19 pandemic: The case of paraisópolis in são paulo, Brazil. Sustainability (switzerland), MDPI AG, 13(3), $1-18$.

Besiou, M., \& Van Wassenhove, L. N. (2020). Humanitarian operations: A world of opportunity for relevant and impactful research. Manufacturing \& Service Operations Management, 22(1), 135-145.

Bezerra, A. C. V., da Silva, C. E. M., Soares, F. R. G., \& da Silva, J. A. M. (2020). Factors associated with people's behavior in social isolation during the covid-19 pandemic. Ciencia e Saude Coletiva, Associacao Brasileira De Pos - Graduacao Em Saude Coletiva, 25, 2411-2421.

Biggerstaff, M., Cauchemez, S., Reed, C., Gambhir, M., \& Finelli, L. (2014). Estimates of the reproduction number for seasonal, pandemic, and zoonotic influenza: A systematic review of the literature. $B M C$ Infectious Diseases, 14(1), 1-20.

Brix-Asala, C., \& Seuring, S. (2020). Bridging institutional voids via supplier development in base of the pyramid supply chains. Production Planning \& Control, 31(11-12), 903-919.

Burch, J. and Bunt, C. (2020), "Can physical interventions help reduce the spread of respiratory viruses?", Cochrane Clinical Answers, available at:https://doi.org/10.1002/cca.2965.

Burkart, C., Besiou, M., \& Wakolbinger, T. (2016). The funding-Humanitarian supply chain interface. Surveys in Operations Research and Management Science, 21(2), 31-45.

BusinessToday.In. (2020), "Global cost of coronavirus: \$11.7 trillion”. Retrived June 29, 2021 from https://www.businesstoday.in/latest/world/story/global-cost-of-coronavirus-this-is-how-much-covid19pandemic-has-cost-the-world-economy-281664-2020-12-16.

Carvalho, H. C., \& Mazzon, J. A. (2020). Embracing complex social problems. Journal of Social Marketing, $10(1), 54-80$.

Cavallieri, F., \& Vial, A. (2012). Favelas na cidade do Rio de Janeiro: O quadro populacional com base no Censo 2010. Coleção Estudos Cariocas, 1, 12. 
Chakrapani, A., Kumar, T., Shivakumar, S., Bhaumik, R., Bhalla, K. \& Prajapati, S. (2020). "A pandemicspecific 'emergency essentials kit'for children in the migrant BoP communities". IEEE International Smart Cities Conference (ISC2), pp. 1-8.

Chakravarty, A. K. (2014). Humanitarian relief chain: Rapid response under uncertainty. International Journal of Production Economics, 151, 146-157.

Corburn, J., Vlahov, D., Mberu, B., Riley, L., Caiaffa, W. T., Rashid, S. F., Ko, A., et al. (2020). Slum health: Arresting COVID-19 and improving well-being in urban informal settlements. Journal of Urban Health, 97(3), 348-357.

Crokidakis, N. (2020). COVID-19 spreading in Rio de Janeiro, Brazil: do the policies of social isolation really work? Chaos, Solitons \& Fractals, Pergamon, 136, 109930.

Dais, I., \& Davis, L. (2020). "A mixed-integer optimization model to allocate monetary donations for food purchases". In Proceedings of the 2016 Industrial and Systems Engineering Research Conference, pp. 747-752.

Darabi, N., \& Hosseinichimeh, N. (2020). "System dynamics modeling in health and medicine: A systematic literature review". System Dynamics Review, 2019, pp. 1-45.

de Camargo Fiorini, P., Jabbour, C. J. C., de Sousa Jabbour, A. B. L., \& Ramsden, G. (2021). The human side of humanitarian supply chains: a research agenda and systematization framework. Annals of Operations Research. https://doi.org/10.1007/s10479-021-03970-z

De Carvalho, C. A., De Almeida Fonseca Viola, P. C, \& Sperandio, N. (2021). "How is Brazil facing the crisis of Food and Nutrition Security during the COVID-19 pandemic?". Public Health Nutrition, Cambridge University Press

Diedrichs, D. R., Phelps, K., \& Isihara, P. A. (2016). Quantifying communication effects in disaster response logistics: A multiple network system dynamics model. Journal of Humanitarian Logistics and Supply Chain Management, 6(1), 24-45.

Đula, I., \& Größler, A. (2021). Inequity aversion in dynamically complex supply chains. European Journal of Operational Research, 291(1), 309-322.

Dumalanede, C., Hamza, K., \& Payaud, M. (2020). Improving healthcare services access at the bottom of the pyramid: The role of profit and non-profit organisations in Brazil. Society and Business Review, 15(3), 211-234.

Dyer, D., Shinder, A., \& Shinder, F. (2000). Alcohol-free instant hand sanitizer reduces elementary school illness absenteeism. Family Medicine, 32(9), 633-638.

EIU. (2019). "Strengthening food systems and the environment through innovation and investment". Retrived December 2, 2020 from https://foodsecurityindex.eiu.com/.

Fawcett, S. E., \& Waller, M. A. (2015). Designing the supply chain for success at the bottom of the pyramid. Journal of Business Logistics. https://doi.org/10.1111/jbl.12096

Fernandes, N. (2020). "Economic effects of coronavirus outbreak (COVID-19) on the world economy". SSRN Electronic Journal, pp. 0-29.

Fontainha, T. C., Leiras, A., de Mello Bandeira, R. A., \& Scavarda, L. F. (2017). Public-private-people relationship stakeholder model for disaster and humanitarian operations. International Journal of Disaster Risk Reduction, 22, 371-386.

Forza, C. (2002). Survey research in operations management: A process-based perspective. International Journal of Operations and Production Management, 22(2), 152-194.

Gallagher, J., \& Hartley, D. (2017). Household finance after a natural disaster: The case of Hurricane Katrina. American Economic Journal: Economic Policy, 9(3), 199-228.

Ghaffarzadegan, N., Lyneis, J., \& Richardson, G. P. (2011). How small system dynamics models can help the public policy process. System Dynamics Review, 27(1), 22-44.

Ghaffarzadegan, N., \& Rahmandad, H. (2020). Simulation-based estimation of the early spread of COVID-19 in Iran: Actual versus confirmed cases. System Dynamics Review, 36(1), 101-129.

Giudice, F., Caferra, R., \& Morone, P. (2020). COVID-19, the food system and the circular economy: Challenges and opportunities. Sustainability, 12(19), 7939.

Global_Food_Security_Index.(2020). “Exploring challenges \& developing solutions”. Retrived June 13, 2020, from https://foodsecurityindex.eiu.com.

Gonçalves, P. (2011). Balancing provision of relief and recovery with capacity building in humanitarian operations. Operations Management Research, 4.1(2), 39-50.

Haynes, N., Cooper, L. A., \& Albert, M. A. (2020). "At the heart of the matter: Unmasking and addressing COVID-19's toll on diverse populations". Circulation, pp. 1-8.

Heaslip, G., \& Kov'acs, G. and Haavisto, I. (2018). Cash-based response in relief: The impact for humanitarian logistics. Journal of Humanitarian Logistics, 8(1), 87-106.

Hou, T., Hou, K., Wang, X., \& Luo, X. (2021). Why I give money to unknown people? An investigation of online donation and forwarding intention. Electronic Commerce Research and Applications 47(101055). 
Hsu, C., Chang, Y., Chen, T., Chang, T., \& Lin, Y. D. (2021). Who donates on line? Segmentation analysis and marketing strategies based on machine learning for online charitable donations in Taiwan. IEEE Access, 9, 52728-52740.

IBGE. (2010). "Censo 2010”. Retrived February 2, 2021 from https://censo2010.ibge.gov.br/.

IBGE. (2019). Conheça o Brasil - População. Retrived September 8, 2021 from. https://educa.ibge. gov.br/jovens/conheca-o-brasil/populacao/18319-cor-ou-raca.html\#: :text=Deacordocomdadosda, $1 \%$ 25comoamarelosouindígenas.

InstitutoDataFavela. (2020). "Coronavírus nas favelas". Retrieved June 14, 2020 from https://0ca2d2b9-e33b402b-b217-591d514593c7.filesusr.com/ugd/eaab21_9837d312494442ceae8c11a751e2a06a.pdf.

Ipea. (2021). "Pandemia afetou mais o trabalho de mulheres, jovens e negros". Retrieved September 8, 2021 from https://www.ipea.gov.br/portal/index.php?option=com_content\&view=article\&id=37963\& Itemid=9

Jefferson, T., Del Mar, C. B., Dooley, L., Ferroni, E., Al-Ansary, L. A., Bawazeer, G. A., van Driel, M. L., et al. (2011). Physical interventions to interrupt or reduce the spread of respiratory viruses. The Cochrane Database of Systematic Reviews. https://doi.org/10.1136/bmj.39393.510347.BE

Johnson, G. (2011). "\$25 million gift earns Smith Global Fundraiser of the year award”. Retrieved April 20, 2019 www.fpmagazine.com.au/site/index.cfm?display=231735\&PageMode=indiv\&page_id=287620

Karanfil, Ö., Hosseinichimeh, N., \& Duggan, J. (2020). "System dynamics and bio-medical modeling". System Dynamics Review

Kermack, W., \& McKendrick, A. G. (1927). A contribution to the mathematical theory of epidemics. Proceedings of the Royal Society of London. Series a, Containing Papers of a Mathematical and Physical Character, 115(772), 700-721.

Khalid, R., Seuring, S., \& Wagner, R. (2020). Evaluating supply chain constructs in the base of the pyramid environment. Journal of Cleaner Production. https://doi.org/10.1016/j.jclepro.2020.122415

Koksal, A., Darrat, M., \& James, K. (2021). Online donation behavior in nonprofit organizations: The role of congruent processing styles. International Journal of Nonprofit and Voluntary Sector Marketing, No. e1708.

Kunz, N., Reiner, G., \& Gold, S. (2014). Investing in disaster management capabilities versus pre-positioning inventory: A new approach to disaster preparedness. International Journal of Production Economics, 157(1), 261-272.

Lau, L. S., Samari, G., Moresky, R. T., Casey, S. E., Kachur, S. P., Roberts, L. F., \& Zard, M. (2020). COVID-19 in humanitarian settings and lessons learned from past epidemics. Nature Medicine, Nature Research, 26(5), 647-648.

Leão, A., Madeira, P., \& Araújo, V. (2021). "Doações de comida despencam na pandemia; saiba como contribuir”. Retrieved May 18, 2021 from https://oglobo.globo.com/sociedade/coronavirus/doacoes-decomida-despencam-na-pandemia-saiba-como-contribuir-24958801.

Leddy, A. M., Weiser, S. D., Palar, K., \& Seligman, H. (2020). A conceptual model for understanding the rapid COVID-19-related increase in food insecurity and its impact on health and healthcare. American Journal of Clinical Nutrition, 112, 1162-1169.

Madhav, N., Oppenheim, B., Gallivan, M., Mulembakani, P., Rubin, E., \& Wolfe, N. (2017). "Pandemics: Risks, impacts, and mitigation". Disease Control Priorities: Improving Health and Reducing Poverty, 3rd ed., The International Bank for Reconstruction and Development, Washington, DC. https://doi.org/ 10.1596/978-1-4648-0527-1_ch17.

McKibbin, W., \& Fernando, R. (2020). "The global macroeconomic impacts of COVID-19: Seven scenarios". SSRN Electronic Journal.

Mejia, J., Urrea, G., \& Pedraza-Martinez, A. J. (2019). Operational transparency on crowdfunding platforms: Effect on donations for emergency response. Production and Operations Management, 28(7), 1773-1791.

Michael Barton, C., Alberti, M., Ames, D., Atkinson, J.A., Bales, J., Burke, E., \& Chen, M., et al. (2020). Call for transparency of COVID-19 models. Science, American Association for the Advancement of Science, May

Ministério. (2020). "SRAG 2020 - Banco de Dados de Síndrome Respiratória”. Retrieved June 15, 2020 from https://shiny.hmg.saude.gov.br/tr/dataset/bd-srag-2020.

Monteiro de Oliveira, M., Fuller, T. L., Brasil, P., Gabaglia, C. R., \& Nielsen-Saines, K. (2020). Controlling the COVID-19 pandemic in Brazil: A challenge of continental proportions. Nature Medicine, Nature Research, October.

Muggy, L., \& Stamm, J. L. H. (2020). Decentralized beneficiary behavior in humanitarian supply chains: Models, performance bounds, and coordination mechanisms. Annals of Operations Research, 284(1), $333-365$.

Nathan, I., \& Benon, M. (2020). "Covid-19 relief food distribution: Impact and lessons for uganda". Pan African Medical Journal, African Field Epidemiology Network, August. 
Noyan, N., Balcik, B., \& Atakan, S. (2016). A stochastic optimization model for designing last mile relief networks. Transportation Science, 50(3), 1092-1113.

Noyan, N., \& Kahvecioğlu, G. (2018). Stochastic last mile relief network design with resource reallocation. Or Spectrum, 40(1), 187-231.

De Oliveira Andrade, R. (2020). The Brazilian slums hiring their own doctors to fight covid-19. The BMJ, BMJ Publishing Group, April. at:https://doi.org/10.1136/bmj.m1597.

Oliveira, C.E. (2020). Favelas pedem doação em dinheiro, e não cesta básica, para apoiar comércio. Retrieved September 28, 2020 from https://economia.uol.com.br/noticias/redacao/2020/05/13/cesta-basica-digitalcufa-favelas.htm.

Oloruntoba, R., Hossain, G. F., \& Wagner, B. (2019). Theory in humanitarian operations research. Annals of Operations Research, 283(1), 543-560.

Pereira, M., \& Oliveira, A. M. (2020). Poverty and food insecurity may increase as the threat of COVID-19 spreads. Public Health Nutrition, 23, 3236-3240.

Peres, I. T., Bastos, L. S. L., Gelli, J. G. M., Marchesi, J. F., Dantas, L. F., Antunes, B. B. P., Maçaira, P. M., et al. (2021). Sociodemographic factors associated with COVID-19 in-hospital mortality in Brazil. Public Health, 192, 15-20.

Phillips, D. (2020). Enormous disparities: Coronavirus death rates expose Brazil's deep racial inequalities". Retrieved July 15, 2020 https://www.theguardian.com/world/2020/jun/09/enormous-disparitiescoronavirus-death-rates-expose-brazils-deep-racial-inequalities.

Piotrowicz, W. D. (2018). In-kind donations, cash transfers and local procurement in the logistics of caring for internally displaced persons: The case of Polish humanitarian NGOs and Ukrainian IDPs. Journal of Humanitarian Logistics and Supply Chain Management, 8(3), 374-397.

Poole, D. N., Escudero, D. J., Gostin, L. O., Leblang, D., \& Talbot, E. A. (2020). Responding to the COVID-19 pandemic in complex humanitarian crises. International Journal for Equity in Health, 19(1), 41.

Rahmandad, H., Lim, T. Y., \& Sterman, J. (2021). Behavioral dynamics of COVID-19: Estimating underreporting, multiple waves, and adherence fatigue across 92 nations. System Dynamics Review, 37(1), $5-31$.

Ribeiro, K. B., Ribeiro, A. F., de Sousa Mascena Veras, M. A., \& de Castro, M. C. (2021). Social inequalities and COVID-19 mortality in the city of São Paulo, Brazil. International Journal of Epidemiology. https:// doi.org/10.1093/ije/dyab022

Richardson, G. P. (2011). Reflections on the foundations of system dynamics. System Dynamics Review, 27(3), 219-243.

Richardson, G. P. (2020). Can systems thinking be an antidote to extensive evil? Systems Research and Behavioral Science, 2019, 1-12.

Rodrigues, M. B., Matos, J. D. P., \& Horta, P. M. (2021). The COVID-19 pandemic and its implications for the food information environment in Brazil. Public Health Nutrition, 24, 321-326.

Rodrigues, V. P., Oliveira, I. C. D., Lorena, G. D., Chaves, D., Larissa, E., Aquino, D. C., \& Viegas, C. V. (2020). Pandemic responses in vulnerable communities: A simulation-oriented approach. Revista De Administracao Publica, 54(4), 1111-1122.

Rodriguez-Morales, A. J., Gallego, V., Escalera-Antezana, J. P., Méndez, C. A., Zambrano, L. I., FrancoParedes, C., Suárez, J. A., et al. (2020). COVID-19 in Latin America: The implications of the first confirmed case in Brazil. Travel Medicine and Infectious Disease, 395(10227), 871-877.

Sabates-Wheeler, R., \& Devereux, S. (2010). Cash transfers and high food prices: Explaining outcomes on Ethiopia's productive safety net programme. Food Policy, 35(4), 274-285.

Sahin, O., Salim, H., Suprun, E., Richards, R., MacAskill, S., Heilgeist, S., \& Al, E. (2020). Developing a preliminary causal loop diagram for understanding the wicked complexity of the COVID-19 Pandemic. Systems, 8(2), 20.

Schwaninger, M., \& Grösser, S. (2016). System dynamics modeling: Validation for quality assurance". System Dynamics: Theory and Applications, 119-138.

SDS (Sytem Dynamics Society). (2020). COVID-19 Resource Page. Retrieved June 20, 2020 from https:// systemdynamics.org/covid-19/.

Sphere Project. (2011). Sphere project: Humanitarian charter and minimum standards in humanitarian response. Geneva, Switzerland.

Srivastava, A., Mukherjee, S., \& Jebarajakirthy, C. (2020). Aspirational consumption at the bottom of pyramid: A review of literature and future research directions. Journal of Business Research, 110, 246-259.

Sterman, J., Oliva, R., Linderman, K., \& Bendoly, E. (2015). System dynamics perspectives and modeling opportunities for research in operations management. Journal of Operations Management, 39, 40.

Sterman, J. D. (2000a). Business dynamics: Systems thinking and modeling for a complex world (5th ed.). McGraw-Hill. 
Sterman, J. D. (2000b). Business dynamics: Systems thinking and modeling for a complex world. Journal of the Operational Research Society. https://doi.org/10.1057/palgrave.jors.2601336

Struben, J. (2020). The coronavirus disease (COVID-19) pandemic: Simulation-based assessment of outbreak responses and postpeak strategies. System Dynamics Review, 36(3), 247-293.

Stummer, C., Zsifkovits, M., \& Doerner, K. F. (2021). Preface: The modeling and simulation of complex systems. Annals of Operations Research, 305, 423-424.

Subrahmanyan, S., \& Gomez-Arias, J. T. (2008). Integrated approach to understanding consumer behavior. Journal of Consumer Marketing, pp. 402-412.

Tavares, F. F., \& Betti, G. (2021). The pandemic of poverty, vulnerability, and COVID-19: Evidence from a fuzzy multidimensional analysis of deprivations in Brazil. World Development, 139, 105307.

Lancet, T. (2020). COVID-19 in Brazil: 'So what?' The Lancet, 395(10235), 1461.

Tortora, P., \& Steensen, S. (2014). Making earmarked funding more effective: Current practices and a way forward., Paris.

Toyasaki, F., \& Wakolbinger, T. (2014). Impacts of earmarked private donations for disaster fundraising. Annals of Operations Research, 221(1), 427-447.

Turrini, L., Besiou, M., Papies, D., \& Meissner, J. (2020). The role of operational expenditures and misalignments in fundraising for international humanitarian aid. Journal of Operations Management, 66(4), $379-417$.

Unger, A., \& Riley, L. W. (2007). Slum health: From understanding to action. PLoS Medicine, 4(10), $1561-1566$.

Unicef. (2020). Donate and help children affected by coronavirus. Retrieved September 28, 2020 from https:// www.unicef.org.uk/donate/coronavirus/

Vega, D. I. (2020). Lockdown, one, two, none, or smart. Modeling containing COVID-19 infection. A conceptual model. Science of the Total Environment. https://doi.org/10.1016/j.scitotenv.2020.138917

Vongkiatkajorn, K., \& Daily, L. (2020). How you can help during the coronavirus outbreak. Retrieved September 28, 2020 from https://www.washingtonpost.com/nation/2020/03/21/how-you-can-helpduring-coronavirus/?arc404=true.

Vozdascomunidades. (2020), "COVID-19 nas favelas", available at: https://painel.vozdascomunidades.com.br/ (accessed 31 May 2020).

von Braun, J. (2008). Food and financial crises: Implications for agriculture and the poor. Retrived December 20, 2020 from https://core.ac.uk/download/pdf/6289061.pdf.

White, M., Nieto, C., \& Barquera, S. (2020). Good deeds and cheap marketing: The food industry in the time of COVID-19. Obesity, 28(9), 1578-1579.

WHO. (2020). Water, sanitation, hygiene and waste management for the COVID-19 virus. World Health Organisation.

Wimschneider, C., Agarwal, N., \& Brem, A. (2020). Frugal innovation for the BoP in Brazil-An analysis and comparison with Asian lead markets. International Journal of Technology Management, 83(1-3), 134-159.

World_Bank_Report. (2020). COVID-19 and SLUMS WBG LAC: A multisectoral approach. Retrieved September 28, 2020 from https://www.thegpsc.org/knowledge-products/urban-poverty-and-housing/ covid-19-and-slums.

Yilmaz, G., \& Blackburn, K. G. (2020). How to ask for donations: a language perspective on online fundraising success. Atlantic Journal of Communication, pp. 1-16.

Zenker, A. L. (2008). Negros são maioria nas favelas, segundo estudo do Ipea. Retrieved September 8, 2021 from https://memoria.ebc.com.br/agenciabrasil/noticia/2008-12-16/negros-sao-maioria-nasfavelas-segundo-estudo-do-ipea.

Zhang, P., Liu, Y., Yang, G., \& Zhang, G. (2020). A multi-objective distributionally robust model for sustainable last mile relief network design problem. Annals of Operations Research, pp. 1-42.

Zhong, Z., Yang, S., \& Duan, Y. (2018). Sustainable development of typhoon prone coastal areas based on SD model. Journal of Coastal Research, 83, 754-769.

Publisher's Note Springer Nature remains neutral with regard to jurisdictional claims in published maps and institutional affiliations. 


\section{Authors and Affiliations}

\section{Luiza Ribeiro Alves Cunha ${ }^{1}$ (D) Bianca B. P. Antunes ${ }^{1}$ (D) \\ Vinícius Picanço Rodrigues ${ }^{2}$ (D) - Paula Santos Ceryno ${ }^{3}$ (D) Adriana Leiras ${ }^{1}$}

$凶$ Adriana Leiras

adrianaleiras@puc-rio.br

Luiza Ribeiro Alves Cunha

luizarac@gmail.com

Bianca B. P. Antunes

biancabpa@yahoo.com.br

Vinícius Picanço Rodrigues

vinicius.picanco@insper.edu.br

Paula Santos Ceryno

paulaceryno@hotmail.com

1 Department of Industrial Engineering, Pontifical Catholic University of Rio de Janeiro, Marquês de São Vicente St., 225 - Gávea, Rio de Janeiro, RJ 22541-041, Brazil

2 Insper Instituto de Ensino E Pesquisa, Quatá St., 300 - Vila Olímpia, São Paulo, SP 04546-042, Brazil

3 Department of Production Engineering, Federal University of the State of Rio de Janeiro, Pasteur Av., 296 - Urca, Rio de Janeiro, RJ 22290-240, Brazil 